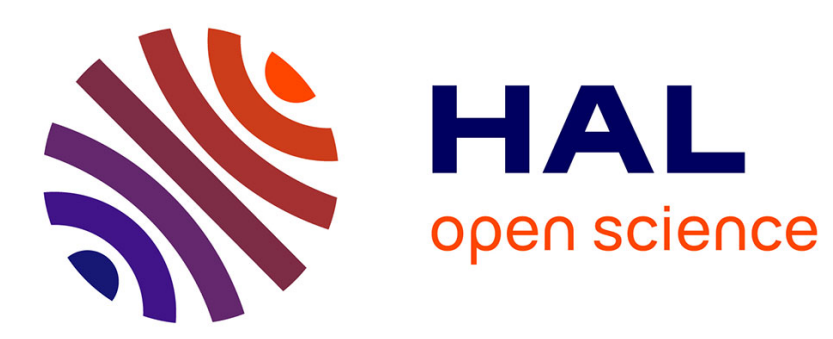

\title{
Variation in the diagenetic response of aragonite archives to hydrothermal alteration
}

\author{
C.L. Pederson, V. Mavromatis, M. Dietzel, S.F.M. Breitenbach, D. Yu, G. \\ Nehrke, A. Immenhauser
}

\section{- To cite this version:}

C.L. Pederson, V. Mavromatis, M. Dietzel, S.F.M. Breitenbach, D. Yu, et al.. Variation in the diagenetic response of aragonite archives to hydrothermal alteration. Sedimentary Geology, 2020, 406, pp.105716. 10.1016/j.sedgeo.2020.105716 . insu-03094170

\section{HAL Id: insu-03094170 \\ https://hal-insu.archives-ouvertes.fr/insu-03094170}

Submitted on 4 Jan 2021

HAL is a multi-disciplinary open access archive for the deposit and dissemination of scientific research documents, whether they are published or not. The documents may come from teaching and research institutions in France or abroad, or from public or private research centers.
L'archive ouverte pluridisciplinaire HAL, est destinée au dépôt et à la diffusion de documents scientifiques de niveau recherche, publiés ou non, émanant des établissements d'enseignement et de recherche français ou étrangers, des laboratoires publics ou privés. 


\section{Journal Pre-proof}

Variation in the diagenetic response of aragonite archives to hydrothermal alteration

C. Pederson, V. Mavromatis, M. Dietzel, C. Rollion-Bard, S.F.M. Breitenbach, D. Yu, G. Nehrke, A. Immenhauser

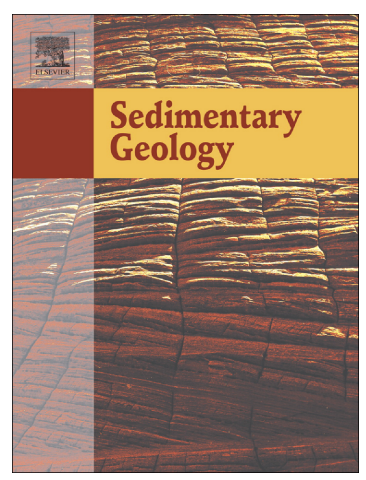

PII: $\quad$ S0037-0738(20)30131-7

DOI: $\quad$ https://doi.org/10.1016/j.sedgeo.2020.105716

Reference: $\quad$ SEDGEO 105716

To appear in: $\quad$ Sedimentary Geology

Received date: $\quad 27$ April 2020

Revised date: $\quad 17$ June 2020

Accepted date: $\quad 19$ June 2020

Please cite this article as: C. Pederson, V. Mavromatis, M. Dietzel, et al., Variation in the diagenetic response of aragonite archives to hydrothermal alteration, Sedimentary Geology (2020), https://doi.org/10.1016/j.sedgeo.2020.105716

This is a PDF file of an article that has undergone enhancements after acceptance, such as the addition of a cover page and metadata, and formatting for readability, but it is not yet the definitive version of record. This version will undergo additional copyediting, typesetting and review before it is published in its final form, but we are providing this version to give early visibility of the article. Please note that, during the production process, errors may be discovered which could affect the content, and all legal disclaimers that apply to the journal pertain.

(C) 2020 Published by Elsevier. 


\section{Variation in the diagenetic response of aragonite archives to hydrothermal alteration}

C. Pederson $^{1 *}$, V. Mavromatis ${ }^{2}$, M. Dietzel ${ }^{3}$, C. Rollion-Bard ${ }^{4},{ }^{5}$ S.F.M Breitenbach, D. Yu ${ }^{1}$, G. Nehrke $^{6}$, A. Immenhauser ${ }^{1}$

${ }^{1}$ Institute for Geology, Mineralogy and Geophysics, Ruhr-University Bochum, Universitätsstr. 150, D-44801, Bochum, Germany

2 Géosciences Environnement Toulouse (GET) CNRS, UMR 5563, 14 av. E. Belin, 31400, Toulouse, France

${ }^{3}$ Institute of Applied Geosciences, Graz, University of Technology, Rechbauerstr. 12, A-8010, Graz, Austria

${ }^{4}$ Université de Paris, Institut de physique du globe de Paris, CNRS, F-75005, Paris, France

5 Department of Geography and Environmental Sciences, Ellison Place, Northumbria University, Newcastle upon Tyne, NE1 8ST, United Kingdom

${ }^{6}$ Alfred Wegener Institute for Polar and Marine Research, Am Handelshafen 12, D-27570, Bremerhaven, Germany 


\section{ABSTRACT}

Diagenesis of carbonate minerals is ubiquitous throughout the geologic record. Alteration is initiated immediately after deposition, or takes place in the endo- and exoskeletons as early as during the lifetime of a given carbonate-secreting biota, and can continue throughout the burial history of carbonate sediments and rocks. Variations in the diagenetic response of carbonate archives pose challenges for the reconstruction of past environmental conditions based on proxy data. This paper comparatively assesses alteration features of different aragonitic materials by experimentally-induced diagenesis. A multitude of factors lead to different reactivity and responses of a given aragonite archive, and provide insight to the interpretation of diagenetically altered material in the rock record. Chosen materials used in this study include relatively organic-rich samples such as coral skeletons and bivalve shells, and organic-lean abiotic carbonates such as speleothems and aragonite single crystals. Obtained datasets include distributions of elements, organics, carbon and oxygen isotope ratios, and crystallographic features. Observed variations in diagenetic responses include mineralogy of the diagenetic phases, rate and extent of mineral transformation, distribution of foreign ions in the crystal lattice (primarily $\mathrm{Sr}, \mathrm{Mg}$, and $\mathrm{S}$ ), and the number of specific processes and products along diagenetic pathways. Alteration is shown to be primarily controlled by the initial diagenetic susceptibility of the sample (including porosimetry and structural characteristics, concentrations of organic material, and primary amounts of trace elements in the carbonate, such as $\mathrm{Mg}$ ). Structural characteristics lead to initial internally "fluid-" or "rock-buffered" conditions, with low porosity and permeability resulting in a greater effect of internal fluids and organics. Differences in the amount of organic content and internal fluids affect transformation rates, secondary mineralogy, and isotope equilibria. Samples with relatively high porosity, high mineral transformation rates, 
and high primary $\mathrm{Mg} / \mathrm{Ca}$, may preferentially form secondary aragonite during fast equilibration with the diagenetic environment. Our results suggest that the degree and nature of diagenetic alteration of aragonite materials are strongly controlled by the micro- to nano-scale internal architecture governing the availability and transfer of aqueous fluids. Results of this study provide significant implications for the interpretation of diagenetic signals in carbonate archives, and have direct significance for the mechanistic understanding of carbonate diagenesis and (paleo)environmental conditions.

Keywords: carbonate, aragonite, diagenesis, paleoenvironment, isotopes, crystallography

\section{Introduction}

Carbonates are widely used proxy archives (Sandberg, 1983; Veizer et al., 1999; Grossman et al., 2008; Immenhauser et al., 2016), providing substantial information on Earth's ambient conditions at the time of deposition, or secretion, throughout the geological record. Due to differences in the diagenetic reactivity of various calcium carbonate polymorphs, a multitude of post-depositional/post-secretion processes - physical, chemical, and biological - can lead to textural and mineralogical alteration affecting the preserved paleoenvironmental information (Müller et al., 2001; Melim et al., 2004; Swart 2015; Bernard et al., 2017). The dichotomy in relative abundance of metastable phases, such as aragonite and high Mg-calcite in modern (sub)tropical marine settings, compared to their relative scarcity in the geologic record (Morse and Mackenzie, 1990), speaks to the ubiquitous alteration of these minerals. Key to understanding these processes is the thermodynamic stability of individual carbonate minerals, 
and kinetically driven dissolution and precipitation reactions (Tardy and Gartner, 1977; Sverjensky, 1984).

This variability of diagenetic reactivity is due to primary differences in susceptibility of a given carbonate archive to alteration, and the duration and physico-chemical conditions existing during diagenesis. Aspects affecting the thermodynamic stability of a carbonate archive include mineralogy at formation/deposition, ultrastructure including porosity and permeability, hence, total reactive surface area, presence of impurities (e.g., $\mathrm{Mg}^{2+}, \mathrm{SO}_{4}^{2-}$ ) in the crystal structure, composition and spatial distribution of organic components, and the presence and type of internal fluids (Walter, 1985; Henrich and Wefer, 1986; Gaffey, 1988; Pederson et al., 2019b). The degree of geochemical disequilibrium between the primary solid and diagenetic fluid (i.e., the diagenetic reactivity) is highly relevant during alteration (Fantle et al., 2010). At a very early diagenetic stage - even during the lifetime of a carbonate secreting organism - biological effects (Winland, 1969; Burton and Walter, 1987; Moore, 1989; Immenhauser et al., 2016) and microbial colonization of, and interaction with, carbonates at the seafloor are relevant parameters (Lange et al., 2018; Ge et al., 2020a). During subsequent diagenetic processes resulting from fluid-solid interactions, parameters such as the physico-chemical composition of the ambient fluid and the fluid:solid volume ratio become increasingly important. Generally, during burial, or when exposed to meteoric fluids, diagenesis will continue (albeit at varying rates) until the system reaches thermodynamic equilibrium, generally seeking equilibrium conditions with the diagenetic fluid at a given time (Putnis and Austrheim, 2013).

During alteration, the transformation of metastable minerals such as aragonite and high$\mathrm{Mg}$ calcite to more stable phases such as calcite and dolomite is observed. Important transformation processes include: replacement of a primary texture by secondary fabrics via 
micro-scale dissolution-reprecipitation reactions (Folk, 1965; Bathurst, 1972; Aissaoui, 1985; Bruni and Wenk, 1985; Gaffey et al., 1991; van der Kooij et al., 2009; Putnis and Austrheim, 2013; Pederson et al., 2015), and the formation of microcrystals during recrystallization (Kaczmarek et al., 2015; Hasiuk et al., 2016). Due to inherent depositional variations of the aforementioned aspects in natural samples, the diagenesis of carbonate minerals varies extensively throughout the geologic record, making it, in some cases, extremely difficult to decipher primary signatures from diagenetic ones. In order to do so, assumptions are made, with potentially large associated errors. However, when properly screened for alteration (often using multiple proxies), the primary signal can be successfully separated from the noise to provide important (paleo)environmental information (e.g., Railsback et al., 2002; Mii et al., 2012; Hood et al., 2018).

The present paper is motivated by the substantial variability of diagenetic features observed in natural carbonates, even when only considering one carbonate mineral. Hence, to assess the diagenetic response of different aragonite materials and the significance of their initial physico-chemical properties to hydrothermal alteration, experiments were performed. Over the last $c a 50$ years, many studies have experimentally investigated the alteration of aragonitic and magnesian calcitic archives (e.g., Kunsler and Goodell, 1970; Walter, 1985; Moshier, 1989; Bischoff et al., 1993; Frisia et al., 2002; Perdikouri et al., 2011; Lucia, 2017; Ritter et al., 2017; Casella et al., 2018; Fichtner et al., 2018; Riechelmann et al., 2018). However, in most of these studies, only one archive (bivalves, brachiopods, echinoderms, etc.) and/or a single diagenetic pathway (often transformation of aragonite to calcite) was examined. Furthermore, most studies aimed to investigate specific alteration aspects, such as microstructure (Walter, 1986), formation 
of microcrystals (McManus, 1982), reaction rates (Bischoff, 1969), or reaction inhibitors and/or catalysts (Bischoff and Fyfe, 1968; Goetschl et al., 2019).

In contrast, work presented herein uses experimental conditions to assess controls and mechanisms between different types of aragonite archives each having a specific internal structure and composition, and initial reactivity. To decipher the impact of fluid availability and ion transfer behavior, i.e., rock-buffered versus fluid-buffered systems, textural and geochemical changes were observed, and a test was performed in the absence of external fluids (dry experiments). We present a diverse suite of analytical approaches to detect organic degradation (elemental distribution and fluorescence microscopy), mineralogical transformation (phase maps and X-ray diffraction), crystallographic changes (electron backscatter diffraction and optical microscopy), and isotope equilibration (spiked experimental fluids, hand-drilled powders, and spot measurements with secondary ion mass spectrometry) to identify any shifts towards textural and geochemical restructuring and equilibration. Alteration features of organic-rich biominerals, such as aragonitic bivalves and corals, are compared to abiogenic, organic-lean aragonitic speleothems and single crystal aragonite, to examine a spectrum of crystal structure, elemental concentration and distribution, internal fluids, and reactive surface area. The aims of this study are to: (i) examine potential differences of diagenetic susceptibility between the four examined archives, (ii) assess any difference in diagenetic responses, and (iii) identify controls and mechanisms, which cause the observed responses to provide broader information for the distinct alteration of individual aragonitic archives and applications to reconstruct past environmental condition.

\section{Materials and Methods}




\section{$2.1 \quad$ Sample Description}

The hydrothermal alteration experiments described here followed a similar protocol to the experiments of Ritter et al. (2017) and Pederson et al. (2019b, 2019c). In this study, four types of aragonitic archives were altered based on an assumed range of diagenetic susceptibility. Progressing from (an assumed) least-to-most reactive of utilized aragonitic archives, these are a (i) single crystal, (ii) speleothem, (iii) bivalve shell, and (iv) coral skeleton (Fig. 1). Subsamples of similar dimensions ( $\mathrm{ca} 2.5 \mathrm{~cm} \times 1 \mathrm{~cm}$ ) were cut from each specimen using a diamond saw blade and water. Care was taken to not affect the mineralogy of the sample during cutting (Staudigel and Swart, 2016). One unaltered subsample and one altered subsample from the same specimen were used for comparison.

The single crystals of aragonite were collected from Bohemia, Czech Republic. The speleothem sample was a stalagmite collected in 2003 from Krem Umsynrang Cave (25 $13^{\prime}$ N, $92^{\circ} 21^{\prime} \mathrm{E}$ ) in NE India (Breitenbach, 2009), originally situated $\mathrm{ca} 50 \mathrm{~m}$ below the cave surface. The stalagmite was $c a 185 \mathrm{~cm}$ long, with the subsamples described here taken near the base of the stalagmite (Breitenbach, 2009). The bivalve specimen (Arctica islandica) was collected from the sea floor off of the NE coast of Iceland, in water with a depth of 40-120 m and a temperature of $3-4^{\circ} \mathrm{C}$ (Locarnini et al., 2006; Jochumsen et al., 2016). The specimen used in this study was $9.75 \mathrm{~cm}$ in length along the ventrical margin, and had a valve thickness ranging from $2-5 \mathrm{~mm}$, indicating an adult stage. The subsamples described here are from $c a 1 \mathrm{~cm}$ from the outer margin of the shell, near the center ventrical. A modern adult Porites sp. coral was collected in 2014 from a reef at Society Island, French Polynesia, at a depth of 2-5 m, with surface temperatures of $26-29^{\circ} \mathrm{C}$ (Global Sea Temperatures, 2019). The coral head was $c a 5.8 \mathrm{~cm}$ high and $4.8 \mathrm{~cm}$ wide. 


\subsection{Experimental alteration}

Subsamples for hydrothermal alteration experiments were placed in individual Teflon-lined autoclaves, with $c a 25 \mathrm{~mL}$ of a synthetic burial fluid containing $100 \mathrm{mM} \mathrm{NaCl}+10 \mathrm{mM} \mathrm{MgCl}$. The artificial fluids were isotopically spiked with an ${ }^{18} \mathrm{O}$-depleted $\mathrm{H}_{2} \mathrm{O}$ (IASON, laboratory reference water W-26; $\delta^{18} \mathrm{O}_{\text {water }}=-395 \%$, Vienna Standard Mean Ocean Water (VSMOW) in a 1:10 ratio with local bi-distilled (with a resistivity of $18.2 \mathrm{M} \Omega \mathrm{cm}^{-1}$ ) lab water (Graz, Austria: $\delta^{18} \mathrm{O}_{\text {water }}=-9 \pm 1 \%$, VSMOW); see also Dietzel et al., 2020). The $\delta^{18} \mathrm{O}_{\text {water }}$ of the ${ }^{18} \mathrm{O}$-depleted water was $c a-47 \%$ VSMOW. The autoclaves were placed in a stainless-steel oven at $160^{\circ} \mathrm{C}$ for four weeks (duration chosen based on results from Ritter et al., 2017). Following the experiments, the autoclaves were removed from the oven and allowed to cool to room temperature. The experimental fluids were filtered through a $0.2 \mu \mathrm{m}$ cellulose acetate filter and saved for later analysis. Solid subsamples were then dried at $40^{\circ} \mathrm{C}$ overnight prior to thin section preparation. The remaining sample in the epoxy mount was preserved for geochemical analysis. Where possible, all data were collected from the given thin section for comparable datasets. For isotope drilling, subsamples in the epoxy plugs were mounted on an aluminum plate using resin, and manually milled for powder. Additional "dry" alteration experiments were performed for a bivalve and speleothem sample in order to observe changes in the absence of experimental fluids by heating pristine speleothem and bivalve subsamples in a Teflon cup to $330^{\circ} \mathrm{C}$ for ten days. Thin sections were prepared and compared with those of the unaltered specimen. Optical light microscopy was used to identify any recrystallization features. Textural features were identified using microscopic methods described below, and are displayed in the supplementary material. Subsamples with no experimental treatment will herein be referred to as "unaltered", whereas the hydrothermally altered subsamples will be referred to as "altered". 


\subsection{X-Ray Diffraction}

Powder X-Ray Diffraction (PXRD) was used to determine the mineralogy of all subsamples. To quantify the minerals present, powder aliquots $(70-100 \mathrm{mg}$ ) were drilled from the remaining thin section epoxy plugs (when possible), either by hand using a Dremel, or with a computercontrolled milling device (CAM 100, vhf, Ammerbuch, Germany). Sample powders were homogenously distributed on a silicon sample carrier, before mounting and aligning them on a rotating goniometer head. Measurements were performed on a PANalytical EMPYREAN diffractometer using copper radiation $\left(\lambda_{1}=0.154 \AA\right)$ equipped with a PIXcel $^{1 \mathrm{D}}$ detector (Medipix2 collaboration, Ruhr-University, Bochum, Germany). Scanning range of 2-Theta was 5 to $80^{\circ}$, with a step size of $0.0131^{\circ}$, and a duration of $598.9 \mathrm{~ms}$. Phases were identified using the software package X'Pert HighScore Plus (PANalytical B.V.). Full reports can be found in the supplementary material.

\subsection{Microscopy}

Thin sections were analyzed using polarization microscopy (Leica DM4500P; Leica Microsystems $\mathrm{GmbH}$, Wetzlar, Germany) to compare petrographic characteristics of all specimen. To identify changes to the amount or distribution of organic constituents, fluorescence microscopy was performed using a Leica EL6000 compact light source coupled to the microscope using a blue light filter (filter set I3 for blue light excitation: excitation 450 to 490 $\mathrm{nm}$, emission $515 \mathrm{~nm})$.

\subsection{Mercury Intrusion Porosimetry (MIP) Analysis}


Porosimetry analysis was performed using MIP analysis at the University of Aberdeen on an AutoPore IV 9500 (Micromeritics, USA). The following properties were quantified: pore size, pore volume, pore diameter, total porosity, permeability, and density. These properties are calculated based on the pressure injection of $\mathrm{Hg}$ into sample pores, due to the well-known contact angle and curvature radius of $\mathrm{Hg}$ (Haines et al., 2015). An inverse relationship of pore size and pressure is observed for. The sensitivity of the system includes pore diameters from 360 to $0.005 \mu \mathrm{m}$. Pore volume was calculated by the volume of remaining mercury following $\mathrm{Hg}$ intrusion. Total porosity (pore volume) was calculated as the ratio of dry bulk density to grain density (equations 1, 2 and 3). Following Haines et al. (2015), the total sample volume $\left(\mathrm{V}_{\mathrm{s}}\right)$ was derived from the volume of mercury $\left(\mathrm{V}_{\mathrm{Hg}}\right)$ and the total volume $\left(\mathrm{V}_{\mathrm{t}}\right)$ :

$V_{s}=V_{t}-V_{H g}$

The dry bulk density, $\rho d$, of the sample was calculated from the sample mass $\left(\mathrm{m}_{\mathrm{s}}\right)$ and total sample volume $\left(\mathrm{V}_{\mathrm{s}}\right)$ :

$\rho d\left(\mathrm{~g} / \mathrm{cm}^{3}\right)=m_{s} V_{s}$

The $\mathrm{Hg}$-porosity $(\mathrm{Hg} \phi)$ was calculated as the ratio of dry bulk density ( $\rho \mathrm{d})$ to the grain density ( $\rho g$ ) (equation 3), which is $2.93 \mathrm{~g} / \mathrm{cm} 3$ for a rock composed purely of aragonite:

$\operatorname{Hg} \phi(\%)=(1-\rho d \rho g 220) \times 100$

MIP analyses were conducted on two unaltered samples for the speleothem, bivalve, and coral samples. Due to the lack of petrographic evidence of porosity for the unaltered single crystal, MIP analysis was not performed on this sample type.

\subsection{Electron backscattered diffraction}


Crystallographic orientation of the altered samples was determined using electron backscattered diffraction (EBSD; Nordlys detector by OXFORD Instruments). The field-emission scanning electron microscope (FESEM, Merlin Gemini II by ZEISS) was operated in high-resolution mode, with a beam energy of $20 \mathrm{kV}$, a sample current of 400-500 pA, a working distance of 25 $\mathrm{mm}$, and a tilt angle of $70^{\circ}$. Data were collected and analyzed on the software packages AZtec and Channel 5 by Oxford Instruments, respectively. Boundary conditions for grain detection were set at a $10^{\circ}$ maximum misorientation of crystal axes. Carbonate mineralogy maps were created using the identified Kicuchi patterns. Step size for map processing were as follows: single crystal $(2 \mu \mathrm{m})$, speleothem $(5.1 \mu \mathrm{m})$, bivalve $(6.5 \mu \mathrm{m})$, and coral $(3.5 \mu \mathrm{m})$.

\subsection{Electron Microprobe Analysis}

A field-emission electron microprobe (EMPA) containing five wavelength-dispersive spectrometers (Cameca SXFiveFE at the Ruhr-University Bochum, Germany) was used to acquire element distribution maps. During data collection, a $15 \mathrm{kV}$ acceleration voltage was used, with a probe current of $170 \mathrm{nA}$, and a fully focused electron beam. Due the beam sensitivity of carbonates, a $10 \mathrm{~nm}$ conductive gold coating was used, which resulted in less sample damage compared to carbon-coated samples. To account for low strontium ( $\mathrm{Sr}$ ) concentrations, the $\mathrm{Sr} \mathrm{K} \alpha$ line was measured simultaneously on two spectrometers. Map dimensions and conditions are as follows: single crystal (2048 x 1536 pixels with $0.5 \mu \mathrm{m}$ step, and a dwell time of $18 \mathrm{~ms}$ per pixel), speleothem (1360 x 1216 pixels with $2 \mu \mathrm{m}$ step, and a dwell time of $35 \mathrm{~ms}$ per pixel), bivalve ( $1250 \times 1250$ pixels with $0.4 \mu \mathrm{m}$ step, and a dwell time of 50 ms per pixel), and coral (1024 x 1024 pixels with $1 \mu \mathrm{m}$ step, and a dwell time of $35 \mathrm{~ms}$ per pixel). 


\subsection{Elemental concentration of fluids and starting material}

Elemental concentrations were analyzed for pre- and post- experimental fluids. Elemental concentrations were measured following the methods of Füger et al. (2019), via a Perkin Elmer Optima 8300 DV Inductively coupled plasma optical emission spectrometer (ICP-OES). Analytical precision was better than $3 \%$.

\subsection{Carbon and oxygen isotope analysis of drilled bulk material}

Remaining epoxy plugs from thin section preparation were mounted and milled on a Sherline 5400 deluxe micromill, using a $0.8 \mathrm{~mm}$ diameter tungsten carbide drill. Individual sample powders (milled lines) were drilled with a width of $4 \mathrm{~mm}$, height of $0.1 \mathrm{~mm}$, and depth of 0.7-1.2 mm. Isotope analyses were performed on a ThermoFisher Scientific MAT253 mass spectrometer, coupled to a Gasbench II, at Ruhr-University Bochum. Aliquots (30-60 $\mu \mathrm{g})$ were reacted after evacuation with helium with $103 \%$ orthophosphoric acid at $70^{\circ} \mathrm{C}$, following the methodology of Breitenbach and Bernasconi (2011). Data were corrected using the international standards CO1, CO8, NBS18, and an in-house standard ISO-A (as reported in Meckler et al., 2014). Data was normalized to the Vienna PeeDee Belemnite (VPDB) in the conventional delta notation and using the standard IAEA 603. External precision was better than $\pm 0.08 \%(1 \sigma)$.

\subsection{Oxygen isotope analysis by Secondary Ion Mass Spectrometry}

Oxygen isotope analyses were performed using Secondary Ion Mass Spectrometry (SIMS) on a CAMECA IMS 1280 ion microprobe at CRPG-CNRS (Nancy, France; Rollion-Bard et al., 2007). A primary $\mathrm{Cs}^{+}$beam with an intensity of $\approx 4 \mathrm{nA}$ was focused to a $c a 15 \mu \mathrm{m}$ spot. To 
compensate for any charging, the normal-incidence electron flood gun was used. Machine conditions included: an entrance slit of $100 \mu \mathrm{m}$, a field aperture of $2500 \mu \mathrm{m}$, and a multicollector slit of $500 \mu \mathrm{m}$, resulting in a mass resolving power $(\mathrm{M} / \Delta \mathrm{M})$ of $\approx 4500$, with which the interference peaks of ${ }^{16} \mathrm{OH}_{2},{ }^{17} \mathrm{OH}$ and ${ }^{16} \mathrm{OD}$ were completely resolved. The energy window was fully opened to allow optimum ion acceptance by the spectrometer. Measurements were conducted in multicollection mode, using two off-axis Faraday cups (L'2 and H1), in which the gains of these were intercalibrated at the beginning of each analytical session. The typical acquisition sequence constituted $60 \mathrm{~s}$ of presputtering, and 30 cycles of $5 \mathrm{~s}$ duration per analysis.

During the presputtering, the backgrounds of the Faraday cups were measured. The measurements were performed with ion intensities of ca $5.5 \times 10^{6}$ counts $/ \mathrm{s}$ on the ${ }^{18} \mathrm{O}^{-}$peak. Two in-house standards (calcite $\mathrm{CCcgA}$ and aragonite $\mathrm{Arg}$ ) were measured for the correction of the instrumental mass fractionation (IMF), based on sample mineralogy (Rollion-Bard et al., 2007), and showed no drift within the analytical uncertainty. Internal precision was generally better than $\pm 0.1 \%$. External reproducibility of the standards was $\pm 0.26 \%$ ( $1 \sigma)$ for aragonite and $\pm 0.20 \%$ for calcite. All $\delta^{18} \mathrm{O}$ values are expressed relative to the VPDB standard.

\subsection{Oxygen isotope fractionation between calcite and water}

The $\delta^{18} \mathrm{O}$ values of the experimental fluids were measured by the common $\mathrm{CO}_{2}-\mathrm{H}_{2} \mathrm{O}$ equilibrium technique (Epstein and Mayeda, 1953) at $20^{\circ} \mathrm{C}$. The $\mathrm{CO}_{2}-\mathrm{H}_{2} \mathrm{O}$ equilibration was carried out on a fully automated device adapted from Horita et al. (1989) coupled to a Finnigan DELTAplus mass spectrometer. Normalization of the raw results versus the VSMOW-SLAP scale was accomplished by using a two-point calibration of in-house water standards calibrated against three international reference materials (VSMOW, GISP, and VSLAP). Calculations of the fluid 
values are based on calcite due to lack of experiments using aragonite. The fractionation factor of oxygen isotopes between calcite and water $\left(\alpha_{\text {calcite-water }}=\left({ }^{18} \mathrm{O} /{ }^{16} \mathrm{O}\right)_{\text {calcite }} /\left({ }^{18} \mathrm{O} /{ }^{16} \mathrm{O}\right)_{\text {water }}\right)$ at isotope equilibrium is calculated by the equation of Coplen (2007):

$10^{3} \ln \left(\alpha_{\text {calcite-water }}\right)=17400 \cdot \mathrm{T}(\mathrm{K})^{-1}-28.6$

The $\alpha_{\text {calcite-water }}$ value decreases accordingly from 1.03020 at $25^{\circ} \mathrm{C}$, to 1.01164 at $160^{\circ} \mathrm{C}$. The $\delta^{18} \mathrm{O}$ composition of calcite precipitated from the experimental fluid at $160^{\circ} \mathrm{C}$ can be calculated by the following expression:

$\delta^{18} \mathrm{O}_{\text {calcite }}(\mathrm{VPDB})=\alpha_{\text {calcite-water }} \cdot\left(\delta^{18} \mathrm{O}_{\text {water }}(\mathrm{VPDB})+10^{3}\right)-10^{3}$

The analyzed $\delta^{18} \mathrm{O}_{\text {water }}$ composition of the experimental fluid was $-47.6 \%$ (VSMOW), which corresponds to $\delta^{18} \mathrm{O}_{\text {water }}=-76.2 \%$ (VPDB) using the $\delta^{18} \mathrm{O}$ scale transformation by Coplen et al. (1983). Considering isotope equilibrium conditions and equation (5), this translates to an $\delta^{18} \mathrm{O}_{\text {calcite }}$ value of calcite formed from the experimental fluid at $160^{\circ} \mathrm{C}$ of $-65.4 \%$ (VPDB). Analogous expressions (4) and (5) have to be considered for aragonite, where Zheng (1999) found from theoretical calculations, calcite to be $2.5 \%$ more positive than aragonite at $160^{\circ} \mathrm{C}$. This would translate to a $\delta^{18} \mathrm{O}_{\text {aragonite value for aragonite formed from the experimental fluid at }}$ $160^{\circ} \mathrm{C}$ of $\mathrm{ca}-67.9 \%$ at isotopic equilibrium (VPDB).

\section{Results}

The data are presented in order as follows: (i) single crystal, (ii) speleothem, (iii) bivalve, and (iv) coral. Overall, variations of altered samples in mineralogy, texture, organic content, elemental, and isotope values indicate different reactivity of the material, and varying degrees and expressions of diagenesis. A generalized summary of results is described in Table 1. 


\subsection{Single crystal aragonite}

\section{Unaltered single crystal sample}

The unaltered aragonite single crystal was determined by PXRD to be $100 \mathrm{wt} . \%$ aragonite. The sample is characterized by an inorganic, single translucent (optically clear) crystal with a welldefined edge, and lacks microfractures or organic material (Fig. 2).

\section{Altered single crystal sample}

Following alteration, the single crystal consisted of 99 wt. $\%$ aragonite and $1 \%$ dolomite via PXRD results. EBSD maps showed a secondary mineral phase (maximum $c a 140 \mu \mathrm{m}$ thick) consisting of a mixture of calcite and dolomite, along with dissolution pitting and microfratures along the outer rim (Fig. 3). The crystallography of the altered single crystal indicates one primary crystal axis direction for the dominant portion of the sample, which retains its original mineralogy (Fig. 3). The neomorphosed portions of the outer rim are characterized by small crystals, lacking preferential orientation (Fig. 3). The rim has relatively lower amounts of $\mathrm{Ca}$, which correspond to relatively higher concentrations of $\mathrm{Mg}$ (Fig. 4). A zonation of $\mathrm{Sr}$ was also observed, with some areas $(1.0-1.5 \mathrm{~mm})$ along the outer rim relatively depleted. Element distribution is further supported by the elemental concentrations in the post-experimental fluids relative to the pre-experimental concentrations. Calcium and $\mathrm{Sr}$ were both removed from the sample (and therefore increased compared to the initial fluid), with $212 \mathrm{mg} / \mathrm{L}$ and $2.5 \mathrm{mg} / \mathrm{L}$ respectively, whereas $115 \mathrm{mg} / \mathrm{L}$ of $\mathrm{Mg}$ was taken up by the sample (therefore decreased compared to the initial fluid) (Fig. 6).

\subsection{Speleothem}




\section{Unaltered speleothem sample}

The unaltered speleothem sample had a mineralogy of 98 wt.\% aragonite and 2 wt.\% calcite based on PXRD measurements. EBSD phase maps also suggested a primary aragonite mineralogy, but with small ( $<5 \mu \mathrm{m}$ in diameter) spots of calcite present (Fig. 3). The speleothem was previously characterized (Breitenbach, 2009) using reflected normal light and near-UV light microscopy to have visible growth bands, consisting of alternating layers of elongated needleshaped opaque crystals comprising a more porous, bright layer, and a dense, translucent microcrystalline layer comprising a less porous, darker layer. The subsamples used here are further defined to have translucent acicular-to-bladed crystal morphologies, and encompass some small amounts of intercrystalline amorphous organic material (Fig. 2). Average porosimetry data $(\mathrm{n}=2)$ includes: average pore diameter $=705 \mathrm{~nm}$, porosity $=26.0 \%$, and permeability $=3.9 \mathrm{mD}$ (Fig. 5). Crystallographic features of the speleothem sample include alternating oriented crystals, with distinct grain boundaries (Fig. 3). Individual crystals in the mapped region can reach over $300 \mu \mathrm{m}$ in length and $50 \mu \mathrm{m}$ in width. Crystal dimensions do not show any zoning or trends in size or axis direction (Fig. 3). Element distribution in the unaltered speleothem indicates homogenous amounts of $\mathrm{Ca}$ and $\mathrm{Sr}$ throughout the sample (Fig. 4). Some spots up to $c a 60 \mu \mathrm{m}$ in size have relatively higher amounts of $\mathrm{Mg}, \mathrm{Al}, \mathrm{Fe}$, and $\mathrm{Si}$ (Fig. 4 and Supplementary Material)

and are likely related to detrital clay inclusions. The sample has average $\delta^{13} \mathrm{C}$ values of $1.0 \%$, and average $\delta^{18} \mathrm{O}$ values of $-5.9 \%$ (VPDB, $\mathrm{n}=2$; Fig. 8 ).

\section{Altered speleothem sample}

PXRD measurements indicated the altered speleothem sample has a mineralogy of 87 wt.\% aragonite and 13 wt.\% brucite $\left(\mathrm{Mg}(\mathrm{OH})_{2}\right)$. Similar to the unaltered sample, however, EBSD 
phase maps indicate a dominant aragonite mineralogy, with the presence of small calcite crystals, with a maximum of $40 \mu \mathrm{m}$ in size, but generally $<5 \mu \mathrm{m}$ (Fig. 3). The EBSD map did not indicate the presence of a $\mathrm{Mg}$-carbonate phase. The sample contains some regions of texturally undisturbed crystals, but a relatively large disturbed region towards the sample center (Fig. 2). In normal light microscopy, darkened areas propagate inwards from both sides of the sample, and correspond to a texturally chaotic region containing small crystals with no preferred direction, and relatively higher amounts of organics (Fig. 2). Adjacent to this area (on both sides), is a region of relatively lower concentration of organic material, and larger secondary crystals. Crystallographic features of the recrystallized region include primarily small crystals ( $c a 120 \mu \mathrm{m}$ in size) with randomly oriented crystals (Fig. 3). Some crystals of larger sizes can reach up to $500 \mu \mathrm{m}$ in length. Similar to the unaltered sample, the altered speleothem has homogenous distribution of $\mathrm{Ca}$ and $\mathrm{Sr}$ throughout the sample (Fig. 4), and small regions (of similar size) of correspondingly elevated amounts of $\mathrm{Mg}, \mathrm{Al}, \mathrm{Fe}$, and Si (Fig. 4 and Supplementary Material). In contrast to the unaltered sample, however, relatively high amounts of $\mathrm{Mg}$ occur along the sample rim, as well as the texturally disturbed region (Fig. 4 and Supplementary Material). The altered speleothem has significantly different isotope values compared to the unaltered sample, with average $\delta^{13} \mathrm{C}$ values of $-5.4 \%$, and average $\delta^{18} \mathrm{O}$ values of $-4.1 \%$ (VPDB; $\mathrm{n}=36$; Fig. 7). SIMS $\delta^{18} \mathrm{O}$ values show lower values with larger ranges, from -4.4 to $-14.0 \%$, and an average of $-8.3 \%$ (VPDB; $\mathrm{n}=37$; Fig. 7A).

\subsection{Bivalve}

\section{Unaltered bivalve sample}


The unaltered bivalve indicated $100 \mathrm{wt} . \%$ aragonite via PXRD analysis. The sample consists of inner and outer shell layers, separated by the pallial myostracum (Fig. 2), and covered by an organic layer (periostracum). The inner shell layer is composed of alternating growth lines (Toland et al., 2000), with higher and lower amounts of inter- and intra-skeletal organics, which can range from 0-5 wt.\% (Marin et al., 2012). The high amounts of organic material appear darker in normal light microscopy, and have a brighter fluorescence (Fig. 2). The organic rich growth layers as well as the outer periostracum bivalve are characterized by higher amounts of Sr and S (Fig. 4). Porosimetry data includes averages $(n=2)$ of the following: pore diameter $=$ $42 \mathrm{~nm}$, porosity $=3.5 \%$, and permeability $=17.8 \mathrm{mD}$ (Fig. 5). The bivalve has average $\delta^{13} \mathrm{C}$ values of 2.4\%, and average $\delta^{18} \mathrm{O}$ values of 3.0\%, typical for the species (Schöne, 2013) ( $\mathrm{n}=33$; Fig. 7). Carbon isotope values show a trend towards more positive values at the outer portion of the shell, whereas $\delta^{18} \mathrm{O}$ values are fairly stable within the majority of the shell, and only become more negative within the outer most periostracum (Fig. 7).

\section{Altered bivalve sample}

PXRD measurements indicated $77 \mathrm{wt} . \%$ aragonite and $23 \mathrm{wt} . \%$ calcite for the altered sample. Mineralogy maps of the altered bivalve shell documented a distinct transition from the preserved aragonite in the inner shell, to the neomorphosed calcite (Fig. 3) towards the outer shell, with a few aragonite "islands" remaining within the outermost layer and neomorphosed areas. A distinct diagenetic front was observed in the altered bivalve, abruptly ending about halfway from the outer shell margin (Fig. 2). Textural features near the inner shell margin are generally preserved, and include organic-rich growth lines and small biominerals (Fig. 2). The altered portions have abundant microfractures at $45-60^{\circ}$ angles relative to the growth bands, and have 
increased fluorescence 50-200 $\mu \mathrm{m}$ from the openings. Crystal size increases at the diagenetic front, which progresses within individual growth bands, remnants of which are preserved, but without the associated organics (Fig. 2). Towards the outer shell layer, crystals become larger in size and more angular, and depositional features such as the growth bands are further lost, and organics devoid (reduced fluorescence and S concentrations, Figs. 2, 3).

Crystallographically, the shell is characterized by a shift from the unaltered portions with well-oriented biominerals, to poorly ordered (up to $73^{\circ}$ of misorientation of the c axis) secondary calcite crystals in the neomorphosed areas (Fig. 3). The neomorphic calcite occurs in three zones, beginning with relatively small crystals $(50-250 \mu \mathrm{m}$ diameter) with the highest misorientation (up to $14^{\circ}$ of the $\mathrm{c}$ axis) near the diagenetic boundary, and progresses to a stabilized zone with larger crystals (up to $0.5 \mathrm{~mm}$ in diameter) and a relatively reduced misorientation $\left(<6^{\circ}\right.$ to the $\mathrm{c}$ axis) (Pederson et al., 2019b). Neomorphosed regions correspond to reduced S concentrations, slightly higher Mg, and slightly lower concentrations of Sr (Fig. 4). Along the outer edges of the sample, elevated amounts of $\mathrm{Mg}$ are observed (see Supplementary Material). The altered sample indicates significant isotopic shifts, with average $\delta^{13} \mathrm{C}$ values of $2.2 \%$, and average $\delta^{18} \mathrm{O}$ values of $-12.2 \%$ ( $n=42$; Fig. 7). Multiple stages of depletion correspond to the textural and crystallographic changes described above, with the most negative $\delta^{18} \mathrm{O}$ values relating to the most progressive zone of recrystallization $\left(\delta^{18} \mathrm{O}\right.$ average $=-29.4 \mathrm{VPDB} ; \mathrm{n}=11$; ranging from 15.7 to $-42.8 \%$ ). SIMS $\delta^{18} \mathrm{O}$ analysis further implies complex recrystallization, with values ranging from -3.2 to $-65.3 \%$ (average $=-26.2 \%$ VPDB, $n=118$; Fig. $7 \mathrm{~A}$ ). This documents that even the texturally preserved inner shell has undergone isotopic exchange, and neomorphic crystals towards the outer portion of the sample are precipitated under near-isotopic equilibrium 
conditions with respect to the experimental fluid $\left(\delta^{18} \mathrm{O}_{\text {calcite }}=-65.3 \%\right.$ VPDB from $\delta{ }^{18} \mathrm{O}_{\text {water }}=-$ 47.6\% VSMOW, from equation 5).

\subsection{Coral}

\section{Unaltered coral sample}

The unaltered coral sample revealed 100 wt.\% aragonitic mineralogy from PXRD results, and displayed typical primary framework and textures, including uniform distribution, size, and structure of pore space, and primary growth lines (Fig. 2). The primary skeleton is composed of elongated, partly radially arranged crystals, and voids $<5 \mu \mathrm{m}$ in diameter. The centers of the coral skeleton contain $c a 150 \mu \mathrm{m}$ diameter crystals, with needle-shaped crystals $<5 \mu \mathrm{m}$ along the rims of some pores. Fluorescence data shows a homogeneous distribution of organic matter, with slightly higher fluorescence along the organic-rich growth lines, and within some organicrich inclusions $(<30 \mu \mathrm{m})$ (Fig. 2). Porosimetry data includes averages $(n=2)$ of the following: pore diameter $=2630 \mathrm{~nm}$, porosity $=41.6 \%$, and permeability $=2607.2 \mathrm{mD}$ (Fig. 5). The skeleton framework has homogeneous $\mathrm{Sr}$ distribution, with slightly higher $\mathrm{Mg}$ and $\mathrm{S}$ concentrations towards the center (Fig. 4). The coral is characterized by average $\delta^{13} \mathrm{C}$ values of 1.9\%o, and average $\delta^{18} \mathrm{O}$ values of $-4.2 \%$ VPDB (Fig. 7).

\section{Altered coral sample}

PXRD results revealed the altered coral specimen still consisted of $100 \%$ aragonite, which was confirmed by the EBSD phase map of the visibly altered region (Fig. 3). The altered coral contains radially-growing fibrous needles $<60 \mu \mathrm{m}$ in diameter infilling the pore spaces of the sample (Fig. 2). Acicular cements form isopachous crusts lining the initial pore spaces along the 
sample surface (Fig. 2). Fluorescence imaging indicated higher amounts of organic matter in the center of the coral skeleton, and significantly lower amounts in the diagenetic cements (Fig. 2). Similar to the unaltered sample, higher amounts of $\mathrm{Mg}$ and $\mathrm{S}$ were observed towards the center of the primary framework (Fig. 4). The secondary cements contain the highest amounts of $\mathrm{Mg}$

and $\mathrm{Sr}$, but the lowest amounts of S. Drilled isotope transects showed covariation of $\delta^{13} \mathrm{C}$ and $\delta^{18} \mathrm{O}$ values, ranging from +0.7 to $-2.3 \%$ (average $-0.8 \%$ VPDB, $\mathrm{n}=46$ ) and -5.3 to $-8.2 \%$ (average $-6.6 \%, n=46$ ), respectively (Fig. 7). The most negative values occur near the outer sample margins. SIMS analysis showed more negative $\delta^{18} \mathrm{O}$ values compared to the drilled transects (average $-13.3 \%, \mathrm{n}=27$ ), and range from -5.0 to $-19.0 \%$ (Fig. 7A).

\section{Interpretation and Discussion}

The closed system hydrothermal experiments conducted in this study should not be seen as direct analogues to the slow processes taking place in natural diagenetic environments. Differences between experimental settings used here relative to natural diagenetic realms include: (i) closed system behavior, (ii) differences in the fluid chemistry and temperature, (iii) the lack of microbial degradation of intercrystalline organic matter and generally the absence of microbepore fluid interaction, and (iv) the lack of a microboring fauna and flora. Our aim was to induce chemical disequilibrium conditions between the fluid phase and the aragonitic material in order to assess alteration features that have important similarities with those found in naturally altered carbonate archives. In order to trigger these features within the duration of the experiments performed here, elevated fluid temperatures were used. Each sample has a specific ultrastucture, a specific reactive (internal and external) surface, and characteristic concentrations and distributions of organic matter. Therefore, the observed contrasting alteration features among 
samples are mainly assigned to the variations of the mineral surface area, fluid inclusions, organic content, and presence of chemical impurities. Many previous studies have focused on specific processes and products of carbonate diagenesis in natural settings (e.g., Anderson et al., 1994; Hendry et al., 1995; Price and Sellwood, 1997; Cherns and Wright, 2000; Dennis et al., 2013), and the comparison of our results with earlier work postulates that similar processes occur during experimental alteration, albeit at much higher rates.

\subsection{Initial diagenetic susceptibility}

Although all samples in this study were composed of aragonite, they respond in very different manners to experimental alteration. The single crystal and bivalve samples primarily transformed to secondary calcite and even to dolomite, whereas the speleothem and coral primarily contain secondary aragonite phases (Fig. 3). Furthermore, textural and crystallographic differences (Figs. 2, 3), as well as geochemical modifications (Fig. 7) indicate different controls on alteration mechanisms. This section uses theoretical considerations and measured data to suggest differences in the initial diagenetic susceptibility of the four carbonate archives discussed here.

Different alteration features have been previously explained by variations in the initial reactivity of the sample, which includes reactive surface area (Jonas et al., 2017; Pederson et al., 2019a) and the presence of foreign ions and impurities (Schroeder, 1969; De Boer, 1977). During mineral-fluid interaction, the available reactive surface area (most important in this study due to the closed system) and rate at which the fluids flow (primarily controlled by porosimetry characteristics such as porosity and permeability) greatly affect the reactivity of a carbonate mineral. Jonas et al. (2017) documented a positive correlation between elemental fluid-solid exchange rate and sample porosity, indicating that higher porosity would lead to a greater 
diagenetic susceptibility of carbonate sediments. Within this study, the coral and speleothem (41.6 and 26\% porosity respectively; Fig. 5) would therefore have higher elemental exchange rates and possibly recrystallization rates compared to the single crystal and bivalve samples $(0$ and 3.5\% porosity, respectively; Fig. 5). High permeability in the coral sample (2607 mD; Fig. 5) suggests an even larger reactive surface area, resulting in higher elemental exchange rates between the solid and fluid compared to the low permeability in the single crystal and speleothem, which result in generally lower diagenetic susceptibility.

Earlier work has also demonstrated that the incorporation of foreign ions and molecules can lead to lower thermodynamic stability due to distortion of the substitution site (Bischoff et al., 1987; Finch and Allison, 2007). Although all experimental fluids had the same initial elemental concentrations, the inherent variations of element and compound incorporation in the four sample types used here should result in variations in inherent reactivity. The incorporation of trace elements/impurities, which substitute for $\mathrm{Ca}^{2+}$ or $\mathrm{CO}_{3}{ }^{2-}$ (e.g., $\mathrm{Sr}, \mathrm{Mg}, \mathrm{Ba}, \mathrm{Fe}$, or $\mathrm{SO}_{4}{ }^{2-}$ ) in the crystal lattice was reported by Kunzler and Goodell (1970) to have less of an effect during alteration of aragonite compared to physical attributes. More recent laboratory studies, however, have documented that substitution ions have a significant effect on the physical structure (Meldrum and Hyde, 2001; Goetschl et al., 2019). Incorporation of $\mathrm{SO}_{4}{ }^{2-}$ to the crystal lattice results in mineral elongation and the temporary attachment of hydrated $\mathrm{SO}_{4}{ }^{2-}$ to the crystal surface results in the formation of voids (Meldrum and Hyde, 2001; Goetschl et al., 2019; Ge et al., 2020), whereas $\mathrm{Mg}^{2+}$ can result in mineral contraction (in calcite and dolomite; Goetschl et al., 2019) or polycrystalline aggregates (Meldrum and Hyde, 2001). Pokroy et al. (2006) documented higher structural distortion in biogenic carbonates compared to inorganic ones, likely due to the incorporation of organic molecules. Therefore, one can assume that the biogenic 
bivalve and coral samples described here may have increased physical "defects", leading to higher alteration potential compared to the single crystal and speleothem.

Higher rates of carbonate precipitation can also lead to deviations from equilibrium conditions, and result in higher or lower amounts of foreign ion incorporation during formation if the partitioning coefficient of the respective ion between solid and fluid $\left(D_{M}\right)$ is below or above unity, respectively (Amiel et al., 1973; Dietzel et al., 2004; Böttcher and Dietzel, 2010; RollionBard and Blamart, 2015; Jamieson et al., 2016; Mavromatis et al., 2018). Some (e.g., Smith et al., 1979; Dietzel et al., 2004) have also documented (aragonitic) biogenic samples to generally have lower $D_{S r}$ values (less $\mathrm{Sr}$ incorporation) compared to inorganic precipitates, likely due to the ability of organisms to exhibit control over their skeleton chemistry (Lowenstam, 1964; Weber, 1973; de Villers et al., 1995; Meibom et al., 2004; Terakado et al., 2010). Furthermore, due to the relatively high concentrations of $\mathrm{Mg}^{2+}(0.0526 \mathrm{~mol} / \mathrm{kg})$ and $\mathrm{SO}_{4}{ }^{2-}(0.0279 \mathrm{~mol} / \mathrm{kg})$ in seawater compared to $\mathrm{Sr}^{2+}(0.00009 \mathrm{~mol} / \mathrm{kg})$ (Duxbury et al., 2018), the incorporation of these substitution ions are likely higher in carbonates formed in marine and hypersaline environments. Therefore, within the range of carbonates at Earth's surface conditions, biogenic aragonite rapidly formed from relatively hot, concentrated fluids, would likely incorporate the highest amount of trace elements and impurities in their crystal lattice, possibly making them less thermodynamically stable and more susceptible to alteration.

The incorporation of elements within an inorganic aragonite crystal lattice, such as the single crystal studied here, is solely controlled by physico-chemical conditions (fluid chemistry, T, pH, etc.) and precipitation kinetics (Kinsman and Holland, 1969; Gaetani and Cohen, 2006; Mavromatis et al., 2015, 2018). During precipitation of aragonite from seawater, the $D_{S r}$ is close to 1, which would result in Sr concentrations of ca 7000 ppm (Kinsman, 1969; Banner, 1995). 
Strontium is readily incorporated in aragonite due to the formation of solid-solution in the aragonite-strontianite system (Kulik et al., 2010), and an increase in precipitation rate does not significantly change the incorporation of Sr into the crystal lattice. In contrast, the incorporation of $\mathrm{Mg}^{2+}$ is by far non-ideal and still hotly debated (Finch and Allison, 2007). For $\mathrm{Mg}^{2+}$, the change of coordination from six in the aqueous ion to nine, if it is assumed to be replacing structural Ca (Rao and Mehrotra, 1978), is unlikely to occur. In contrast to calcite, aragonite is known to preferentially incorporate metal ions with ion radii larger than $\mathrm{Ca}^{2+}$ (Böttcher and Dietzel, 2010).

Although inorganic, speleothems have a wide range of minor and trace element concentrations $(\mathrm{Mg}=100$ to $131 \mathrm{ppm}$; Finch et al., 2001), with increased concentrations generally resulting from increased aridity, low fluid flow, and low growth rates (Fairchild and Treble, 2009; Wassenburg et al., 2016; Arienzo et al., 2017). The aragonitic shell of Arctica islandica reportedly has $\mathrm{Mg}$ concentrations from 68 to $99 \mathrm{ppm}$ in bulk samples, but are 2-3 times higher near the organic-rich growth lines (Schöne et al., 2010). Coral skeletons typically contain 1000-2000 ppm of $\mathrm{Mg}$ (Swart, 1981), with the majority of Mg in Porites corals occurring within organic matter or a highly disordered crystal phase (Finch and Allison, 2007; 2008). This would further indicate that aragonitic corals may have the highest trace element incorporation and associated lowest thermodynamic stability, with the opposite to occur in the single crystal. A biogenic origin, warm seawater temperatures, high precipitation rates, and overall large volumes of internal porosity, would all lead to a relatively high alteration potential of the carbonate materials.

Based on the factors discussed above, the four carbonate archives investigated here can be placed into a relative order of diagenetic susceptibility from least-to-most susceptible: (i) single 
crystal aragonite, (ii) speleothem, (iii) bivalve, and (iv) coral. It should be noted that the speleothem and bivalve have some conflicting aspects (relatively high porosity and low permeability in the speleothem, and relatively low porosity and high permeability in the bivalve, leading to complex fluid interactions), and so their order may be sample specific.

\subsection{Mineralogy: $\mathrm{Mg} / \mathrm{Ca}$ ratios and reaction rates}

With reference to the diagenetic reactivity of the sample materials, the mineralogy of the neomorphic phase is of relevance (Fig. 3). The aragonite single crystal builds a rim composed of dolomite and calcite, the bivalve undergoes aragonite-to-calcite alteration, whereas the speleothem and coral skeleton primarily contain secondary aragonite phases (Fig. 3). Furthermore, porosity in the coral sample is partially occluded by secondary aragonite needle cements (Figs. 3, 4). Variations of mineralogy in diagenetic phases and elemental incorporation in calcite and aragonite have been attributed to variations in fluid chemistry, rock:fluid interactions, reactive surface area, and precipitation rate. Elemental concentrations and ratios, such as $\mathrm{Mg} / \mathrm{Ca}$, of the precipitating fluid significantly impact nucleation kinetics of carbonate minerals (Kitano, 1962; Folk and Land, 1975; Möller and Kubanek, 1976; Mucci and Morse, 1983; Purgstaller et al., 2016, 2017a). Both laboratory studies (at high and low temperatures) and natural analogues have shown high $\mathrm{Mg} / \mathrm{Ca}$ ratios to inhibit calcite nucleation and growth, and subsequently favor the formation of aragonite and high-Mg calcite (Kitano, 1962; Möller and Kubanek, 1976; Nancollas and Sawada, 1982; Fernandez-Diaz et al., 1996; Dietzel et al., 2004; Purgstaller et al., 2016, 2017a, 2017b; Konrad et al., 2018). This is because aragonite nuclei are more likely to reach the required surface area-to-volume ratio to form secondary crystals during 
volume-to-volume dissolution-reprecipitation compared to calcite (Kitano, 1962; Bischoff and Fyfe, 1968; Perdikouri et al., 2011, 2013).

Reactive surface area (porosity) has been shown (Jonas et al., 2017) to positively correlate to elemental $(\mathrm{Mg})$ exchange rate and rate of aragonite replacement. Precipitation/dissolution rates are likely the main parameters controlling the mineralogy of the secondary phase. Aragonite formation is favored at high $\mathrm{Mg} / \mathrm{Ca}$ ratios and above a given saturation state (Zhong and Mucci, 1989), whereas low rates of replacement favor the nucleation of calcite (Burton and Walter, 1987; Deleuze and Brantley, 1997). It should be noted here, that because the experiments in this study were conducted at elevated fluid temperatures compared to natural marine and shallow burial diagenetic settings, it is likely that the fluid phase rapidly achieved nearequilibrium conditions with respect to aragonite, and the transformation features likely occurred at thermodynamic equilibrium. The latter feature is not necessarily valid for the nucleation of magnesite and dolomite. At elevated temperatures, the high fluid-to-solid ratio combined with high $\mathrm{Mg} / \mathrm{Ca}$ ratios and the thermal energy of the system, allow the kinetic barrier that controls growth of Mg-carbonates to be overcome, so their formation is possible.

These finding suggest that high experimental $\mathrm{Mg} / \mathrm{Ca}$ ratios, and the high porosity of the coral and speleothem samples (41.6 and 26\% porosity, respectively; Fig. 5) likely led to high dissolution and precipitation rates at these temperatures, favoring the formation of secondary aragonite. The differences in relative $\mathrm{Mg}$ and $\mathrm{Sr}$ concentrations of the secondary phases in the coral skeleton and speleothem pore spaces may be due to differences in the origin of aragonite formation (inorganic versus biogenic), as well as the reactive surface area and re-crystallization rates. The secondary aragonite needles in the coral may have relatively higher $\mathrm{Sr}$ concentrations compared to the biogenic aragonitic skeleton (Fig. 4) due to the higher $D_{S r}$ of inorganic aragonite 
compared to biominerals (Dietzel et al., 2004). The relatively Mg-enriched secondary aragonite in the speleothem may indicate slightly faster precipitation rates, as higher aragonite precipitation rates have been correlated to lower $D_{S r}$ values, but higher $D_{M g}$ values (Gabitov et al., 2011). It may also indicate the presence of a Mg-carbonate phase, as is suggested by the PXRD results (see Supplementary Material). Due to the inorganic origin of the speleothem, the large difference in Sr concentrations (as observed in the coral aragonite) should not be expected.

In contrast, the secondary calcite and dolomite phases in the aragonite single crystal and bivalve (Fig. 3) are likely due to the relatively low porosity and hindrance of elemental exchange (via dissolution/precipitation), resulting in lower replacement rate, and preferential calcite formation. In this case, the temperature effect and fluid chemistry would primarily control the $D_{S r}$ values, resulting in relatively lower incorporation of $\mathrm{Sr}$, while $D_{M g}$ values would result in higher incorporation of Mg within the secondary calcite phases (Fig. 4) due to their influence from higher precipitation rates. The relatively low observed differences in $\mathrm{Sr}$ concentrations between aragonite biominerals and secondary calcite of the bivalve shell (Fig. 4), are likely due to the consistent and ideal substitution of $\mathrm{Sr}$ in both the aragonite and calcite crystal structure (Finch and Allison, 2007). High calcite precipitation rates result in high $D_{S r}$ (Kinsman and Holland, 1969; Gabitov and Watson, 2006; Gabitov et al., 2014) and $D_{M g}$ values (Mavromatis et al., 2013; Goetschl et al., 2019), possibly explaining a relatively slower transformation rate for the single crystal and bivalve compared to the speleothem and coral skeleton.

\subsection{Textures: Rock-buffered versus fluid-buffered systems and the role of internal organics}

Three types of "internal" fluids may occur within the carbonate samples discussed here: (i) aqueous fluid trapped within pores and as thin films at crystal boundaries, (ii) fluid inclusions, 
and (iii) fluids related to organic material (both intra- and intercrystalline). As the trapped fluids within pore spaces would be easily liberated or evaporated following sampling (and heating), they can be disregarded as having an effect on the alteration process. Previous studies have documented the importance of these internal fluids during the alteration of carbonate archives (James, 1974; Gvirtzman and Friedman, 1977; Bruni and Wenk, 1985; Constantz, 1986; Gaffey et al., 1991; Hendry et al., 1995). Internal fluids are particularly important in biogenic sediments, where organics and associated fluids - primarily controlled by the shell structure (Gaffey et al., 1991; Kobayashi and Samata, 2006) - can reach up to 3 wt.\% (Gaffey, 1988; Lécuyer and O'Neil, 1994). Most modern carbonates (both inorganic and biogenic) contain varying amounts of organic matter (Golubic et al., 1975; Sandstrom et al., 1986; Ramseyer et al., 1997; Ingalls et al., 2003; Muscatine et al., 2005; Swart, 2015), with organic-lean samples often escaping early alteration (Cuif et al., 2010). Many authors (e.g., Pingitore, 1982; Ritter et al., 2017; Casella et al., 2017; Higgins et al., 2018) have documented that physical properties (porosity, permeability, ultrastructure, etc.) and internal features (organics and fluids) control fluid:solid interactions within carbonate sediments, and therefore play a major role in the extent and expression of diagenesis.

We suggest here that the diagenetic effect of internal fluids and organics correspond to internal "rock-buffered" or "fluid-buffered" dynamics within a given sample. Fluid-buffered (or “open") systems are most common in the near-surface or shallow-burial realm (Gale et al., 2004; Bjørlykke and Jahren, 2012), with geochemical exchange between pore fluids, which can easily circulate through a medium. In contrast, rock-buffered (or "closed") systems restrict the flow of fluids through the medium, particularly along grain boundaries or through fissures, and the rates of alteration (pore fluids, fluid inclusions, organic-bound fluids, etc.) are significantly slower and 
often occur along reaction fronts (Bathurst, 1972; Bruni and Wenk, 1985; Gaffey et al., 1991; van der Kooij et al., 2009; Pederson et al., 2019b). Moreover, mineralogical and geochemical reaction fronts may be spatially disconnected, both at the scales of the experiments performed here and in volumetrically much larger, natural reaction aureoles (Ferry et al., 2002; Pederson et al., 2019b).

The internal structure and components of carbonate sediments can also lead to various alteration mechanisms. Jonas et al. (2017) demonstrated that, at elevated temperatures, rockbuffered alteration is generally diffusion-driven, with the host-rock dominating the petrographic and geochemical signature of the secondary phase. Many systems have shown to vary in their behavior between given proxies, with more fluid-buffered behavior for one (i.e., O) and more rock-buffered for another (i.e., C, Ca, or Mg; Pingitore, 1982; Geske et al., 2012; Chanda and Fantle, 2017), adding further complexity to the discussion. We suggest that internal fluids and organics can have a large effect on the diagenetic progression of carbonate archives, and play a much larger role in more internally rock-buffered systems, with increasing solid-to-fluid ratios at a local level. This results in increased control over the textural and isotopic composition of any secondary precipitates. Based on the results of this study, the sample types can be separated into fluid-buffered or rock-buffered internal systems.

\subsubsection{Rock-buffered conditions}

The alteration pathway of the aragonite single crystal clearly commenced as an internally rockbuffered system, as it initially has no observable internal porosity (Fig. 2). This suggests that any internal fluids would potentially have at least some effect on its alteration. However, in the absence of significant amounts of fluid inclusions or organics (Fig. 2), the replacement processes 
should proceed along the sample margin and reaction fronts, likely as a coupled dissolutionprecipitation mechanism. This is confirmed by an alteration rim consisting of small crystals lacking preferential orientation, and hydrothermally induced (thermal expansion) fissures, with textural alteration only occurring within those areas (Figs. 2-4). Perdikouri et al. (2011) observed similar results in alteration experiments of inorganic single crystals, with a fluid-mediated dissolution-reprecipitation replacement mechanism along the sample rim and within cracks and pores produced during alteration.

\subsubsection{Semi-rock-buffered conditions}

The bivalve sample could be described as a semi-rock-buffered system, as it has relatively low porosity (3.5\%; Fig. 5), likely resulting in a limited amount of external fluid circulation within the sample. However, a relatively high permeability (average $=17.8 \mathrm{mD}$; Fig. 5) would allow any internal fluids to move through the pore spaces. The first stage of neomorphism in the bivalve sample occurs within the organic-rich growth bands (Figs. 2, 3), and is characterized by (i) small calcite crystals within larger subcrystals, with a metastable fabric due internal crystal strain (up to $14^{\circ}$ misorientation; Fig. 3 and supplementary material; Okumura et al., 2011), suggesting aragonite-to-calcite diagenesis in its nascent state. Diagenesis of biogenic carbonates can be crystallographically assumed due to a positive correlation of crystal size and degree of misorientation, and degree of alteration (Casella et al., 2017; McCoy et al., 2018). (ii) Reduced organic content is also observed (reduced fluorescence, Fig. 2, and reduced S, Fig. 4), which is sensible as the $D_{\text {suffate }}$ in calcite is $\ll<1$ (Busenberg and Plummer, 1985). (iii) This neomorphosed phase also has a low degree of oxygen isotope equilibration with the experimental fluids $\left(\delta^{18} \mathrm{O}\right.$ average $=-8.8 \%$ VPDB; Pederson et al., 2019b; compared to calcite at isotope equilibrium 
$\delta^{18} \mathrm{O}_{\text {calcite }}=-65.4 \%$ VPDB), further suggesting a primary control by the internal structure and components of the primary phase. Due to the limited accessibility of the experimental fluids to the sample interior, this dissolution-reprecipitation process is likely facilitated, to some degree, by internal organics and fluids. In the case of the aragonitic bivalve studied here, these appear as intercrystalline matrices surrounding individual prisms or tablets (Lutz and Rhodes, 1977; Carriker et al., 1980; Schöne et al., 2010; Casella et al., 2018; Pérez-Huerta and Laiginhas, 2018), as intracrystalline matrices, and both soluble and insoluble compounds (Schöne et al., 2010). During heating, organics are liberated (Gaffey, 1988; Gaffey et al., 1991), releasing $\mathrm{CO}_{\mathrm{x}}$ $\left(\mathrm{CO}\right.$ and $\left.\mathrm{CO}_{2}\right)$ and small amounts of associated fluids. This likely triggers the initial formation of a diagenetic phase in the bivalve, mediating very small-scale dissolution-reprecipitation within the organic-rich growth bands (Fig. 3). The dissolution of water-soluble organics, or the thermal breakdown of these compounds, has been shown to result in increased permeability and circulation pathways for external fluids, and an increased reactive surface area (Gaffey 1987; Gaffey, 1991; Casella et al., 2017). The ability of these internal fluids was also proven in the dry experiments, which revealed extensive neomorphism in the absence of an external fluid phase (Supplementary Material).

A second neomorphic phase in the A. islandica subsample occurs near the outer (upper) sample surface, and is characterized by: (i) larger calcite crystals, that are, judging from the $<6^{\circ}$ misorientation, rather thermodynamically stable (Fig. 3 and supplementary material), and (ii) lower $\delta^{18} \mathrm{O}$ values (average $=-29.4 \%$ VPDB; Pederson et al., 2019b). SIMS data indicate isotope equilibrium conditions with the experimental fluid $\left(5^{\text {th }}\right.$ point from the outer-most position of profile 1: $\delta^{18} \mathrm{O}_{\text {calcite }}=-65.3 \%$ VPDB versus the theoretical equilibrium value of $-65.4 \%$; Supplementary Material), suggesting a larger influence of the experimental fluids compared to 
the first phase of neomorphism. The minor decrease in $\mathrm{Sr}$ from the least-to-most-altered portions of the valve subsample (982 to 737 ppm; Pederson et al., 2019b) suggests that solid state transformation is unlikely. In contrast, elemental exchange that proceeds via dissolution-recrystallization is a more probable diagenetic mechanism. In summary, disequilibrium within a semi-rock-buffered system resulted in the formation of a first neomorphic calcite phase via dissolution-reprecipitation due to the limited access of experimental fluids within the sample, and was mainly controlled by the primary features. A second neomorphic calcite phase formed due to thermodynamic instability of the first calcite phase under more fluid-buffered conditions. Hendry et al. (1995) described similar multi-stage early alteration of Jurassic bivalves, primarily controlled by the distribution of the shell organic matrix. This multi-phase recrystallization may be more common in internally rock-buffered systems, relatively high in internal fluids and organics.

\subsubsection{Semi-fluid-buffered conditions}

In contrast, the diagenesis of the speleothem occurred along one primary pathway as well as along the outer rim of the sample. The primary zone of alteration (Fig. 3) is characterized by (i) secondary crystals lacking preferential orientation (Fig. 3), (ii) reduced fluorescence (Fig. 2), (iii) an increased $\mathrm{Mg}$ content (Fig. 4), and (iv) slightly lower $\delta^{18} \mathrm{O}$ values (average $\delta^{18} \mathrm{O}_{\text {aragonite }}=-$ $4.5 \%$ VPDB, $\mathrm{n}=11$ ) compared to the non-recrystallized region (average $=-3.8 \%$ VPDB, $\mathrm{n}=$ 25) (Fig. 7). The speleothem has low permeability (average $=2.9 \mathrm{mD}$ ), but a fairly high porosity (average $=26.0 \%)($ Fig. 5). This implies that the sample surface as well as available pore spaces act as pathways for the alteration fluids, which may represent semi-fluid-buffered dynamics. However, the generally low organic content (Breitenbach, 2009) may allow the low permeability to control the initial diagenetic phase. Whereas the organics incorporated in biominerals are both 
intra- and intercrystalline, speleothems have been shown to incorporate submicroscopic units of adsorbed organic matter (Ramseyer et al., 1997). As relatively small misordered crystals (Fig. 3) occur towards the center of the sample near the diagenetic front, and correspond to darkened organics (Fig. 2) and relatively high fluorescence and $\mathrm{Mg}$ concentrations (Fig. 4), it can be assumed that the internal components likely affect the initial recrystallization via dissolutionrecrystallization within a semi-rock-buffered system. The limited influence of internal fluids within the speleothem is confirmed by the dry experiments, which showed little-to-no alteration in the absence of external fluids (Supplementary Material). It should be noted, however, that in hydrothermal experiments, internal fluids may play a more important role as liquid is not evaporated (as in dry experiments), and thus internal fluids may still be able to interact with the solid throughout the experiment.

SIMS measurements confirm the semi-rock-buffered system with respect to oxygen isotopes, with minimum $\delta^{18} \mathrm{O}$ values within the recrystallized region reaching -14.0\%o (VPDB). This is far from isotopic equilibrium with the experimental fluid $\left(\delta^{18} \mathrm{O}_{\text {aragonite }}=-67.9 \% \mathrm{VPDB}\right)$, and can be explained by being buffered by the primary sample characteristics. These data indicate that during heating, external fluids permeated the sample, bringing isotopically light fluid and also $\mathrm{Mg}$ ions to the alteration front. The low permeability, however, only allowed a small external influence during diagenesis. Alteration of the speleothem likely began with removal and redistribution of any internal organic material present, but due to low permeability and low volumes of internal fluids, limited external fluids circulated throughout the sample, resulting in initially smaller secondary crystals (similar to the first phase of recrystallization in the bivalve sample). These crystals likely continued to grow and slightly reorder to form larger, 
thermodynamically more stable crystals towards the outer edge of the sample (Fig. 3), suggesting recrystallization within semi-fluid buffered conditions.

\subsubsection{Fluid-buffered conditions}

The Porites coral is characterized by the most internally open system, and corresponds to diagenetic alteration within "fluid-buffered" conditions. With over an order of magnitude higher porosity (average $=41.6 \%)$ and over two magnitudes higher permeability (average $=2607.2 \mathrm{mD})$ compared to the other samples (Fig. 5), the ability of fluids to effectively circulate through the pore spaces results in high rates of alteration. The diagenetic phases include (i) partial aragonitearagonite recrystallization of the primary skeleton, and (ii) precipitation of inorganic aragonitic pore filling cements (Fig. 2). The distinction of the two phases is based on crystallographic features (Fig. 3), elemental concentrations (Fig. 4), and (partially) SIMS isotope analyses (Fig. 7A). The initial aragonite-aragonite recrystallization correlates to dissolution or thermal breakdown of organic material (Figs. 2,4). Compared to bivalves, corals generally have a lower amount of organic material (0.01-0.5 wt.\% TOC; Ingalls et al., 2003), which primarily occurs between fibrous crystals (Ramseyer et al., 1997). The coral sample released the highest (and only detectable) amount of $\mathrm{S}(0.07 \mathrm{mmol})$ into the alteration fluids during the experiment (Fig. 6), suggesting that the skeletal organic material was easily removed from the coral, but apparently did not play a major role in the initial recrystallization process due to the low concentrations and the overall fluid-buffered system. This was confirmed in an earlier study (Pederson et al., 2019c), which showed removal of organics but no aragonite-aragonite recrystallization at temperatures of $130^{\circ} \mathrm{C}$. Therefore, although organics (and fluids released from these) may play a role in the more rock-buffered systems, their significance in fluid-buffered systems is negligible. Despite the 
fluid-buffered alteration, the isotopic composition of the altered coral does not reflect isotope equilibrium with the experimental fluids, with only slightly more negative $\delta^{18} \mathrm{O}$ values compared to the unaltered sample (altered average $=-6.6 \%, \mathrm{n}=47$, versus unaltered average $=-4.2 \%$ o VPDB, $\mathrm{n}=33$; Fig. 7). This is likely due to only minor recrystallization via micro-scale volumeby-volume dissolution-precipitation along a thin veneer reaction front within the primary skeleton.

The secondary pore-filling aragonite cements are characterized by (i) radially-precipitated acicular aragonite needles up to $60 \mu \mathrm{m}$ in length and a few $\mu \mathrm{m}$ in width (Fig. 2), (ii) relatively higher Sr and Mg, but lower S concentrations (Fig. 4), and (iii) random crystal orientations (Fig. 3). Following initial alteration of the primary framework, the fluid chemistry must have remained supersaturated with respect to aragonite, and the precipitation of pore-filling aragonite needles took place. SIMS $\delta^{18} \mathrm{O}$ data indicate more negative values (minimum $=-18.9 \%$ VPDB) compared to the drilled powders (Fig. 7B), but still indicate significant isotope disequilibrium with the experimental fluids $\left(\delta^{18} \mathrm{O}_{\text {aragonite eq. }}=-67.9 \%\right.$ VPDB$)$. The SIMS data likely represent a mixture of both primary skeleton aragonite and secondary cements. This could be due to two reasons: (i) the SIMS spots represent a mixed bulk analysis of primary and recrystallized material, and/or (ii) during initial dissolution along the pore space, the isotopic signature of the secondary cements was partially controlled by the primary phase. Both options are considered as viable. As it is sometimes difficult to detect exactly sampling location during SIMS analysis, it is possible that the sample spots combine a bit of both phases. The isotopic values, however, are so far from equilibrium that we cannot ignore an inheritance of the primary signature within the diagenetic phase. Although this is generally explained by accessibility of the fluid phase to the reaction site, and is more common in rock-buffered conditions (Peridikouri et al., 2011; Ahm et 
al., 2018; Higgins et al., 2018), the partial inheritance of the isotopic signature within the fluidbuffered coral must result from another unknown mechanism. This may be due to very fast aragonite-aragonite dissolution-reprecipitation in high porosity and permeability materials (Jonas et al., 2017).

\section{Conclusions}

Variations in the diagenetic response of four aragonitic materials (single crystal, speleothem, coral, and bivalve) to hydrothermal alteration include the mineralogy of secondary mineral phases (aragonite, calcite, and $\mathrm{Mg}$-calcite), rates and amounts of recrystallization and neomorphism, exchange and incorporation of elements (primarily $\mathrm{Sr}, \mathrm{Mg}$, and $\mathrm{S}$ ) in the crystal lattice, and number of number of diagenetic pathways and products. These variations are primarily controlled by different initial alteration potentials (including different structural characteristics), differences in the type and amount of organic material, and amounts of substitution ions (such as $\mathrm{Mg}$ ). These parameters lead to either internal "fluid-" or "rockbuffered" conditions, but care must be taken, as a diagenetic system might be fluid-buffered for one proxy and rock-buffered for another. Low permeability and low internal fluids/organics - as in the aragonite single crystal and speleothem - may lead to lower reaction rates, lower amounts of recrystallization/neomorphism, and lower degrees of isotopic re-equilibration during diagenesis. High amounts of internal organics/fluids, high permeability, and low porosity - as in the bivalve - may result in step-wise isotopic and crystallographic equilibration during alteration. Lastly, samples with high $\mathrm{Mg} / \mathrm{Ca}$ ratios, high precipitation/dissolution rates, and relatively high porosity - as in the coral skeleton, and partially in the case of the speleothem - may coincide with the formation of secondary aragonite and fast equilibration with the diagenetic environment. 
Results shown here have significance for the interpretation of carbonate archive research and the mechanisms controlling aragonite diagenesis, especially regarding crystallographic and isotopic equilibration.

\section{Acknowledgements}

This work was supported by the DFG-FWF collaborative research initiative CHARON II (DFG Forschergruppe 1644, FWF-I3028-N29). Leonie Weiss is acknowledged for the assistance in textural data collection, and isotope sample drilling. Sylvia Riechelmann is thanked for running the isotope samples, and Rolf Neuser for producing much of the EBSD results. Niels Jöns is thanked for the production of the EMPA maps, and Nordine Bouden for his technical help with the ion probe.

\section{References}

Ahm, A.S.C., Bjerrum, C.J., Blättler, C.L., Swart, P.K., Higgins, J.A., 2018. Quantifying early marine diagenesis in shallow-water carbonate sediments. Geochimica et Cosmochimica Acta 236, 140-159.

Anderson, T. F., Popp, B. N., Williams, A. C., Ho, L. Z., Hudson, J. D., 1994. The stable isotopic records of fossils from the Peterborough Member, Oxford Clay Formation (Jurassic), UK: palaeoenvironmental implications. Journal of the Geological Society 151, 125-138.

Aissaoui, D.M., 1985. Botryoidal aragonite and its diagenesis. Sedimentology 32, 345-361. 
Amiel, A.J., Friedman, G.M., Miller, D.S., 1973. Distribution and nature of incorporation of trace elements in modern aragonitic corals. Sedimentology 20, 47-64.

Arienzo, M.M., Swart, P.K., Broad, K., Clement, A.C., Pourmand, A., Kakuk, B., 2017. Multiproxy evidence of millennial climate variability from multiple Bahamian speleothems. Quaternary Science Reviews 161, 18-29.

Banner, J.L., 1995. Application of the trace element and isotope geochemistry of strontium to studies of carbonate diagenesis. Sedimentology 42, 805-824.

Bathurst, R. G., 1972. Carbonate sediments and their diagenesis 12. Elsevier, Amsterdam, pp. 657.

Bernard, S., Daval, D., Ackerer, P., Pont, S., Meibom, A., 2017. Burial-induced oxygen-isotope re-equilibration of fossil foraminifera explains ocean paleotemperature paradoxes. Nature Communications 8, 1-10.

Bischoff, J.L., 1969. Temperature controls on aragonite-calcite transformation in aqueous solution. American Mineralogist: Journal of Earth and Planetary Materials 54, 149-155.

Bischoff, J.L., Fyfe, W.S., 1968. Catalysis, inhibition, and the calcite-aragonite problem; [Part] 1, The aragonite-calcite transformation. American Journal of Science 266, 65-79. 
Bischoff, W.D., Bertram, M.A., Mackenzie, F.T., Bishop, F.C., 1993. Diagenetic stabilization pathways of magnesian calcites. Carbonates and Evaporites 8, 82-89.

Bjørlykke, K., Jahren, J., 2012. Open or closed geochemical systems during diagenesis in sedimentary basins: Constraints on mass transfer during diagenesis and the prediction of porosity in sandstone and carbonate reservoirs. AAPG Bulletin 96, 2193-2214.

Böttcher, M.E., Dietzel, M., 2010. Metal-ion partitioning during low-temperature precipitation and dissolution of anhydrous carbonates and sulphates. European Mineralogical Union Notes in Mineralogy 10, 139-187.

Breitenbach, S., 2009. Changes in monsoonal precipitation and atmospheric circulation during the Holocene reconstructed from stalagmites from Northeastern India. Ph.D. dissertation, University of Potsdam, Germany.

Breitenbach S.F.M., Bernasconi S., 2011. Carbon and oxygen isotope analysis of small carbonate samples (20 to $100 \mu \mathrm{g}$ ) with a GasBench II preparation device. Rapid Communications in Mass Spectrometry 25, 1-5. https://doi.org/10.1002/rcm.5052.

Bruni, S. F., Wenk, H. R., 1985. Replacement of aragonite by calcite in sediments from the San Cassiano Formation (Italy). Journal of Sedimentary Research 55, 159-170. 
Burton, E. A., Walter, L. M., 1987. Relative precipitation rates of aragonite and Mg calcite from seawater: Temperature or carbonate ion control? Geology 15, 111-114.

Busenberg, E., Plummer, L. N. (1985). Kinetic and thermodynamic factors controlling the distribution of $\mathrm{SO}_{3}{ }^{2-}$ and $\mathrm{Na}^{+}$in calcites and selected aragonites. Geochimica et Cosmochimica Acta 49, 713-725.

Carriker, M.R., Palmer, R.E., Prezant, R.S., 1980. Functional ultramorphology of the dissoconch valves of the oyster Crassostrea virginica. In: Hillman, R.E. (Ed.), Proceedings of the National Shellfisheries Association Volume 70, MPG Communications, Plymouth, Massachusetts, pp. 139-183.

Casella, L.A., Griesshaber, E., Yin, X., Ziegler, A., Mavromatis, V., Müller, D., Ritter, A.C., Hippler, D., Harper, E.M., Dietzel, M., Immenhauser, A., 2017. Experimental diagenesis: insights into aragonite to calcite transformation of Arctica islandica shells by hydrothermal treatment. Biogeosciences 14, http://dx.doi.org/10.5194/bg-14-1461-2017.

Casella, L.A., He, S., Griesshaber, E., Fernández-Díaz, L., Greiner, M., Harper, E.M., Jackson, D.J., Ziegler, A., Mavromatis, V., Dietzel, M., Eisenhauer, A., 2018. Hydrothermal alteration of aragonitic biocarbonates: assessment of micro-and nanostructural dissolution-reprecipitation and constraints of diagenetic overprint from quantitative statistical grain-area analysis. Biogeosciences 15, 7451-7484. 
Chanda, P., Fantle, M. S., 2017. Quantifying the effect of diagenetic recrystallization on the Mg isotopic composition of marine carbonates. Geochimica et Cosmochimica Acta 204, 219-239.

Cherns, L., Wright, V. P., 2000. Missing molluscs as evidence of large-scale, early skeletal aragonite dissolution in a Silurian sea. Geology 28, 791-794.

Constantz, B., 1986. The primary surface area of corals and variations in their susceptibility to diagenesis. In Reef Diagenesis (pp. 53-76). Springer, Berlin, Heidelberg.

Coplen, T. B., 2007. Calibration of the calcite-water oxygen-isotope geothermometer at Devils Hole, Nevada, a natural laboratory. Geochimica et Cosmochimica Acta 71, 3948-3957.

Coplen, T. B., Kendall, C., Hopple, J., 1983. Comparison of stable isotope reference samples. Nature 302, 236-238.

Cuif, J. P., Dauphin, Y., Sorauf, J. E., 2010. Biominerals and fossils through time. Cambridge University Press.

De Boer, R.B., 1977. Stability of Mg-Ca carbonates. Geochimica et Cosmochimica Acta 41, 265-270.

Deleuze, M., Brantley, S.L., 1997. Inhibition of calcite crystal growth by $\mathrm{Mg}^{2+}$ at $100{ }^{\circ} \mathrm{C}$ and 100 bars: Influence of growth regime. Geochimica et Cosmochimica Acta 61, 1475-1485. 
Dennis, K. J., Cochran, J. K., Landman, N. H., Schrag, D. P., 2013. The climate of the Late Cretaceous: New insights from the application of the carbonate clumped isotope thermometer to Western Interior Seaway macrofossil. Earth and Planetary Science Letters 362, 51-65.

de Villiers, S., Nelson, B.K., Chivas, A.R., 1995. Biological controls on coral $\mathrm{Sr} / \mathrm{Ca}$ and $\delta^{18} \mathrm{O}$ reconstructions of sea surface temperatures. Science 269, 1247-1249.

Dietzel, M., Gussone, N., Eisenhauer, A., 2004. Co-precipitation of $\mathrm{Sr}^{2+}$ and $\mathrm{Ba}^{2+}$ with aragonite by membrane diffusion of $\mathrm{CO}_{2}$ between 10 and $50^{\circ} \mathrm{C}$. Chemical Geology 203, 139-151.

Dietzel, M., Purgstaller, B., Kluge, T., Leis, A., Mavromatis, V., 2020. Oxygen and clumped isotope fractionation during the formation of $\mathrm{Mg}$ calcite via an amorphous precursor. Geochimica et Cosmochimica Acta. https://doi.org/10.1016/j.gca.2020.02.032.

Duxbury, A.C., Byrne, R.H., Mackenzie, F.T., 2017. Seawater. Proc., Encyclopædia Britannica. https://www.britannica.com/science/seawater.

Epstein, S., Mayeda, T., 1953. Variation of $\mathrm{O}^{18}$ content of waters from natural sources. Geochimica et Cosmochimica Acta 4, 213-224.

Fairchild, I.J., Treble, P.C., 2009. Trace elements in speleothems as recorders of environmental change. Quaternary Science Reviews 28, 449-468. 
Fantle, M. S., Maher, K. M., DePaolo, D. J., 2010. Isotopic approaches for quantifying the rates of marine burial diagenesis. Reviews of Geophysics 48, https://doi.org/10.1029/2009RG000306.

Fernandez-Diaz, L., Putnis, A., Prieto, M., Putnis, C.V., 1996. The role of magnesium in the crystallization of calcite and aragonite in a porous medium. Journal of Sedimentary Research, 66, 482-491.

Ferry, J.M., Wing, B.A., Penniston-Dorland, S.C., Rumble, D., 2002. The direction of fluid flow during contact metamorphism of siliceous carbonate rocks: new data for the Monzoni and Predazzo aureoles, northern Italy, and a global review. Contributions to Mineralogy and Petrology 142, 679-699.

Fichtner, V., Strauss, H., Mavromatis, V., Dietzel, M., Huthwelker, T., Borca, C.N., Guagliardo, P., Kilburn, M.R., Göttlicher, J., Pederson, C.L., Griesshaber, E., 2018. Incorporation and subsequent diagenetic alteration of sulfur in Arctica islandica. Chemical Geology 482, 72-90.

Finch, A.A., Shaw, P.A., Weedon, G.P. and Holmgren, K., 2001. Trace element variation in speleothem aragonite: potential for palaeoenvironmental reconstruction. Earth and Planetary Science Letters 186, 255-267.

Finch, A.A., Allison, N., 2007. Coordination of $\mathrm{Sr}$ and $\mathrm{Mg}$ in calcite and aragonite. Mineralogical Magazine 71, 539-552. 
Finch, A.A., Allison, N., 2008. Mg structural state in coral aragonite and implications for the paleoenvironmental proxy. Geophysical Research Letters 35, https://doi.org/10.1029/2008GL033543.

Folk, R.L., 1965. Some aspects of recrystallization in ancient limestones. In: Purdy, E., (Ed.), Dolomitization and Limestone Diagenesis. The Society of Economic Paleontologists and Mineralogists, Oklahoma, USA.

Folk, R.L., Land, L.S., 1975. Mg/Ca ratio and salinity: two controls over crystallization of dolomite. AAPG bulletin 59, 60-68.

Frisia, S., Borsato, A., Fairchild, I.J., McDermott, F., Selmo, E.M., 2002. Aragonite-calcite relationships in speleothems (Grotte de Clamouse, France): environment, fabrics, and carbonate geochemistry. Journal of Sedimentary Research 72, 687-699.

Füger, A., Konrad, F., Leis, A., Dietzel, M., Mavromatis, V., 2019. Effect of growth rate and pH on lithium incorporation in calcite. Geochimica et Cosmochimica Acta 248, 14-24.

Gabitov, R.I., Watson, E.B., 2006. Partitioning of strontium between calcite and fluid. Geochemistry, Geophysics, Geosystems 7, https://doi.org/10.1029/2005GC001216 . 
Gabitov, R.I., Schmitt, A.K., Rosner, M., McKeegan, K.D., Gaetani, G.A., Cohen, A.L., Watson, E.B., Harrison, T.M., 2011. In situ $\delta^{7} \mathrm{Li}, \mathrm{Li} / \mathrm{Ca}$, and $\mathrm{Mg} / \mathrm{Ca}$ analyses of synthetic aragonites. Geochemistry, Geophysics, Geosystems 12, https://doi.org/10.1029/2010GC003322.

Gabitov, R.I., Sadekov, A., Leinweber, A., 2014. Crystal growth rate effect on Mg/Ca and Sr/Ca partitioning between calcite and fluid: An in situ approach. Chemical Geology 367, 70-82.

Gaetani, G.A., Cohen, A.L., 2006. Element partitioning during precipitation of aragonite from seawater: a framework for understanding paleoproxies. Geochimica et Cosmochimica Acta 70, 4617-4634.

Gaffey, S. J., 1988. Water in skeletal carbonates. Journal of Sedimentary Research 58, 397-414.

Gaffey, S. J., Kolak, J. J., Bronnimann, C. E., 1991. Effects of drying, heating, annealing, and roasting on carbonate skeletal material, with geochemical and diagenetic implications. Geochimica et Cosmochimica Acta 55, 1627-1640.

Gale, J. F., Laubach, S. E., Marrett, R. A., Olson, J. E., Holder, J., \& Reed, R. M. (2004). Predicting and characterizing fractures in dolostone reservoirs: Using the link between diagenesis and fracturing. In: Braithwaite, C.J.R., Rizzi, G., Darke, G. (Eds.), The Geometry and Petrogenesis of Dolomite Hydrocarbon Reservoirs. Geological Society, London, pp. 177-192. 
Ge, Y., Lokier, S.W., Hoffmann, R., Pederson, C.L., Neuser, R.D., Immenhauser, A., 2020a. Composite micrite envelopes in the lagoon of Abu Dhabi and their application for the recognition of ancient firm-to hardgrounds. Marine Geology 423, https://doi.org/10.1016/j.margeo.2020.106141.

Ge, Y., Pederson, C.L., Lokier, S.W., Traas, J.P., Nehrke, G., Neuser, R.D., Goetschl, K.E., Immenhauser, A., 2020b. Late Holocene to Recent aragonite-cemented transgressive lag deposits in the Abu Dhabi lagoon and intertidal sabkha. Sedimentology, https://doi.org/10.1111/sed.12707.

Geske, A., Zorlu, J., Richter, D.K., Niedermayr, A., Immenhauser, A., 2012. Impact of diagenesis and low grade metamorphosis on isotope $\left(\delta^{26} \mathrm{Mg}, \delta^{13} \mathrm{C}, \delta^{18} \mathrm{O}\right.$ and $\left.{ }^{87} \mathrm{Sr} /{ }^{86} \mathrm{Sr}\right)$ and elemental (Ca, Mg, Mn, Fe and Sr) signatures of Triassic sabkha dolomites. Chemical Geology $332,45-64$.

Global Sea Temperatures, 2019. www.seatemperature.org/australia-pacific/frenchpolynesia/uturoa-may.htm. "Utuoroa Sea Temperatures May Average, French Polynesia Sea Temperatures".

Goetschl, K.E., Purgstaller, B., Dietzel, M., Mavromatis, V., 2019. Effect of sulfate on magnesium incorporation in low-magnesium calcite. Geochimica et Cosmochimica Acta 265, 505-519. 
Golubic, S., Perkins, R.D., Lukas, K.J., 1975. Boring microorganisms and microborings in carbonate substrates. In: Frey, R.W. (Ed.), The study of trace fossils. Springer, Berlin, Heidelberg, New York, pp. 229-259

Grossman, E.L., Yancey, T.E., Jones, T.E., Bruckschen, P., Chuvashov, B., Mazzullo, S.J., Mii, H.S., 2008. Glaciation, aridification, and carbon sequestration in the Permo-Carboniferous: The isotopic record from low latitudes. Palaeogeography, Palaeoclimatology, Palaeoecology 268, $222-233$.

Gvirtzman, G., Friedman, G.M., 1977. Sequence of Progressive Diagenesis in Coral Reefs: Sediments and Diagenesis. In: Frost, S.H., Weiss, M.P., Saunders, J.B. (Eds.), Reefs and Related Carbonates - Ecology and Sedimentology. American Association of Petroleum Geologists, Tulsa, Oklahoma, pp. 357-380.

Haines, T.J., Neilson, J.E., Healy, D., Michie, E.A., Aplin, A.C., 2015. The impact of carbonate texture on the quantification of total porosity by image analysis. Computers \& Geosciences 85 , $112-125$.

Hasiuk, F.J., Kaczmarek, S.E., Fullmer, S.M., 2016. Diagenetic origins of the calcite microcrystals that host microporosity in limestone reservoirs. Journal of Sedimentary Research 86, 1163-1178. 
Hendry, J. P., Ditchfield, P. W., Marshall, J. D., 1995. Two-stage neomorphism of Jurassic aragonitic bivalves; implications for early diagenesis. Journal of Sedimentary Research 65, 214224.

Henrich, R., Wefer, G., 1986. Dissolution of biogenic carbonates: effects of skeletal structure. Marine Geology 71, 341-362.

Higgins, J.A., Blättler, C.L., Lundstrom, E.A., Santiago-Ramos, D.P., Akhtar, A.A., Crüger Ahm, A.S., Bialik, O., Holmden, C., Bradbury, H., Murray, S.T., Swart, P.K., 2018. Mineralogy, early marine diagenesis, and the chemistry of shallow-water carbonate sediments. Geochimica et Cosmochimica Acta 220, 512-534.

Horita, J., Ueda, A., Mizukami, K., Takatori, I., 1989. Automatic $\delta \mathrm{D}$ and $\delta^{18} \mathrm{O}$ analyses of multiwater samples using $\mathrm{H}_{2}$ - and $\mathrm{CO}_{2}$-water equilibration methods with a common equilibration setup. International Journal of Radiation Applications and Instrumentation 40, 801-805.

Immenhauser, A., Schoene, B.R., Hoffmann, R., Niedermayr, A., 2016. Mollusc and brachiopod skeletal hard parts: intricate archives of their marine environment. Sedimentology 63, 1-59.

Ingalls, A.E., Lee, C., Druffel, E.R., 2003. Preservation of organic matter in mound-forming coral skeletons. Geochimica et Cosmochimica Acta, 67, 2827-2841. 
James, N.P., 1974. Diagenesis of scleractinian corals in the subaerial vadose environment. Journal of Paleontology, 785-799.

Jamieson, R.A., Baldini, J.U., Brett, M.J., Taylor, J., Ridley, H.E., Ottley, C.J., Prufer, K.M., Wassenburg, J.A., Scholz, D., Breitenbach, S.F., 2016. Intra-and inter-annual uranium concentration variability in a Belizean stalagmite controlled by prior aragonite precipitation: A new tool for reconstructing hydro-climate using aragonitic speleothems. Geochimica et Cosmochimica Acta 190, 332-346.

Jochumsen, K., Schnurr, S. M., Quadfasel, D., 2016. Bottom temperature and salinity distribution and its variability around Iceland. Deep Sea Research Part I: Oceanographic Research Papers 111, 79-90.

Jonas, L., Müller, T., Dohmen, R., Immenhauser, A., Putlitz, B., 2017. Hydrothermal replacement of biogenic and abiogenic aragonite by Mg-carbonates-Relation between textural control on effective element fluxes and resulting carbonate phase. Geochimica et Cosmochimica Acta 196, 289-306.

Kaczmarek, S.E., Fullmer, S.M., Hasiuk, F.J., 2015. A universal classification scheme for the microcrystals that host limestone microporosity. Journal of Sedimentary Research 85, 11971212. 
Kinsman, D.J., 1969. Interpretation of $\mathrm{Sr}^{2+}$ concentrations in carbonate minerals and rocks. Journal of Sedimentary Research 39, 486-508.

Kinsman, D.J., Holland, H.D., 1969. The co-precipitation of cations with $\mathrm{CaCO}_{3}-\mathrm{IV}$. The coprecipitation of $\mathrm{Sr}^{2+}$ with aragonite between $16^{\circ}$ and $96^{\circ} \mathrm{C}$. Geochimica et Cosmochimica Acta 33, 1-17.

Kitano, Y., Hood, D.W., 1962. Calcium carbonate crystal forms formed from sea water by inorganic processes. Journal of the Oceanographical Society of Japan 18, 141-145.

Kobayashi, I., Samata, T., 2006. Bivalve shell structure and organic matrix. Materials Science and Engineering: C 26, 692-698.

Konrad, F., Purgstaller, B., Gallien, F., Mavromatis, V., Gane, P., Dietzel, M., 2018. Influence of aqueous $\mathrm{Mg}$ concentration on the transformation of amorphous calcium carbonate. Journal of Crystal Growth 498, 381-390.

Kulik, D.A., Vinograd, V.L., Paulsen, N., Winkler, B., 2010. (Ca, Sr)CO 3 aqueous-solid solution systems: From atomistic simulations to thermodynamic modelling. Physics and Chemistry of the Earth, Parts A/B/C 35, 217-232.

Kunzler, R.H., Goodell, H.G., 1970. The aragonite-calcite transformation; a problem in the kinetics of a solid-solid reaction. American Journal of Science 269, 360-391. 
Lange, S.M., Krause, S., Ritter, A.C., Fichtner, V., Immenhauser, A., Strauss, H., Treude, T., 2018. Anaerobic microbial activity affects earliest diagenetic pathways of bivalve shells. Sedimentology 65, 1390-1411.

Lecuyer, C., O'Neil, J. R., 1994, Stable isotope compositions of fluid inclusions in biogenic carbonates. Geochimica et Cosmochimica Acta 58, 353-363.

Locarnini, R., Mishonov, A., Antonov, J., Boyer, T., Garcia, H., 2006. Temperature. World Ocean Atlas 2005. NOAA Atlas NESDIS.

Lowenstam, H.A., 1964. Sr/Ca ratio of skeletal aragonites from the recent marine biota at Palau and from fossil gastropods. In: Craig, H., Miller, S.L, Wasserburg, G.J. (Eds.) Isotopic and Cosmic Chemistry. North-Holland Publishing Company, Amsterdam, pp. 114-132.

Lucia, F.J., 2017. Observations on the origin of micrite crystals. Marine and Petroleum Geology 86, 823-833.

Lutz, R.A., Rhoads, D.C., 1977. Anaerobiosis and a theory of growth line formation. Science 198, 1222-1227. 
Marin, F., Le Roy, N., Marie, B., 2012. The formation and mineralization of mollusk shell. Front Biosci 4, 125.

Mavromatis, V., Gautier, Q., Bosc, O., Schott, J., 2013. Kinetics of Mg partition and Mg stable isotope fractionation during its incorporation in calcite. Geochimica et Cosmochimica Acta 114, 188-203.

Mavromatis, V., Montouillout, V., Noireaux, J., Gaillardet, J., Schott, J., 2015. Characterization of boron incorporation and speciation in calcite and aragonite from co-precipitation experiments under controlled $\mathrm{pH}$, temperature and precipitation rate. Geochimica et Cosmochimica Acta 150, 299-313.

Mavromatis, V., Goetschl, K.E., Grengg, C., Konrad, F., Purgstaller, B., Dietzel, M., 2018. Barium partitioning in calcite and aragonite as a function of growth rate. Geochimica et Cosmochimica Acta 237, 65-78.

McCoy, S. J., Kamenos, N. A., Chung, P., Wootton, T. J., Pfister, C. A., 2018. A mineralogical record of ocean change: Decadal and centennial patterns in the California mussel. Global change biology 24, 2554-2562.

McManus, K.M., 1982. The aqueous aragonite to calcite transformation: rate, mechanisms, and its role in the development of neomorphic fabrics. M.Sc. thesis, Virginia Polytechnic Institute and State University, Virginia, pp. 72, http://hdl.handle.net/10919/87231. 
Meckler A.-N., Ziegler M., Breitenbach S.F.M., Millan I., Bernasconi S., 2014. Long-term performance of the Kiel carbonate device with a new correction scheme for clumped isotope measurements. Rapid Communications in Mass Spectrometry 28, 1705-1715.

Meibom, A., Cuif, J.P., Hillion, F., Constantz, B.R., Juillet-Leclerc, A., Dauphin, Y., Watanabe, T., Dunbar, R.B., 2004. Distribution of magnesium in coral skeleton. Geophysical Research Letters 31, https://doi.org/10.1029/2004GL021313.

Meldrum, F.C., Hyde, S.T., 2001. Morphological influence of magnesium and organic additives on the precipitation of calcite. Journal of Crystal Growth 231, 544-558.

Melim, L. A., Swart, P. K., Eberli, G. P., 2004. Mixing-zone diagenesis in the subsurface of Florida and the Bahamas. Journal of Sedimentary Research 74, 904-913.

Mii, H.S., Shi, G.R., Cheng, C.J., Chen, Y.Y., 2012. Permian Gondwanaland paleoenvironment inferred from carbon and oxygen isotope records of brachiopod fossils from Sydney Basin, southeast Australia. Chemical Geology 291, 87-103.

Moore, C.H., 1989. Carbonate diagenesis and porosity. Elsevier, Amsterdam, pp. 337.

Morse, J.W., Mackenzie, F.T., 1990. Geochemistry of sedimentary carbonates. Elsevier, Amsterdam, pp. 707. 
Moshier, S.O., 1989. Microporosity in micritic limestones: a review. Sedimentary Geology 63, $191-213$.

Möller, P., Kubanek, F., 1976. Role of magnesium in nucleation processes of calcite, aragonite and dolomite. Neues Jarb Abh 126, 199-220.

Mucci, A., Morse, J.W., 1983. The incorporation of $\mathrm{Mg}^{2+}$ and $\mathrm{Sr}^{2+}$ into calcite overgrowths: influences of growth rate and solution composition. Geochimica et Cosmochimica Acta 47, 217233.

Müller, A., Gagan, M. K., McCulloch, M. T., 2001. Early marine diagenesis in corals and geochemical consequences for paleoceanographic reconstructions. Geophysical Research Letters 28, 4471-4474.

Muscatine, L., Goiran, C., Land, L., Jaubert, J., Cuif, J.P., Allemand, D., 2005. Stable isotopes $\left(\delta^{13} \mathrm{C}\right.$ and $\left.\delta^{15} \mathrm{~N}\right)$ of organic matrix from coral skeleton. Proceedings of the National Academy of Sciences 102, 1525-1530.

Nancollas, G.H., Sawada, K., 1982. Formation of scales of calcium carbonate polymorphs: the influence of magnesium ion and inhibitors. Journal of Petroleum Technology 34, 645-652. 
Okumura, T., Suzuki, M., Nagasawa, H., Kogure, T., 2011. Microstructural variation of biogenic calcite with intracrystalline organic macromolecules. Crystal Growth \& Design 12, 224-230.

Pederson, C.L., McNeill, D.F., Klaus, J.S., Swart, P.K., 2015. Deposition and diagenesis of marine oncoids: implications for development of carbonate porosity. Journal of Sedimentary Research 85, 1323-1333.

Pederson, C.L., Klaus, J.S., Swart, P.K., Mcneill, D.F., 2019a. Deposition and early diagenesis of microbial mud in the Florida Everglades. Sedimentology 66, 1989-2010.

Pederson, C., Mavromatis, V., Dietzel, M., Rollion-Bard, C., Nehrke, G., Jöns, N., Jochum, K.P., Immenhauser, A., 2019b. Diagenesis of mollusc aragonite and the role of fluid reservoirs. Earth and Planetary Science Letters 514, 130-142.

Pederson, C.L., Weiss, L., Mavromatis, V., Rollion-Bard, C., Dietzel, M., Neuser, R., Immenhauser, A., 2019c. Significance of fluid chemistry throughout diagenesis of aragonitic Porites corals-An experimental approach. The Depositional Record 5, 592-612.

Perdikouri, C., Kasioptas, A., Geisler, T., Schmidt, B.C., Putnis, A., 2011. Experimental study of the aragonite to calcite transition in aqueous solution. Geochimica et Cosmochimica Acta 75, 6211-6224. 
Perdikouri, C., Piazolo, S., Kasioptas, A., Schmidt, B.C., Putnis, A., 2013. Hydrothermal replacement of aragonite by calcite: interplay between replacement, fracturing and growth. European Journal of Mineralogy 25, 123-136.

Pérez-Huerta, A., Laiginhas, F., 2018. Preliminary data on the nanoscale chemical characterization of the inter-crystalline organic matrix of a calcium carbonate biomineral. Minerals 8, https://doi.org/10.3390/min8060223.

Pingitore, N.E., Jr., 1982. The role of diffusion during carbonate diagenesis. Journal of Sedimentary Petrology 52, 27-39.

Pokroy, B., Fitch, A.N., Lee, P.L., Quintana, J.P., El'ad, N.C., Zolotoyabko, E., 2006. Anisotropic lattice distortions in the mollusk-made aragonite: a widespread phenomenon. Journal of Structural Biology 153, 145-150.

Price, G. D., Sellwood, B. W., 1997. "Warm” palaeotemperatures from high Late Jurassic palaeolatitudes (Falkland Plateau): Ecological, environmental or diagenetic controls? Palaeogeography, Palaeoclimatology, Palaeoecology 129, 315-327.

Purgstaller, B., Mavromatis, V., Immenhauser, A., Dietzel, M., 2016. Transformation of Mgbearing amorphous calcium carbonate to $\mathrm{Mg}$-calcite-in situ monitoring. Geochimica et Cosmochimica Acta 174, 180-195. 
Purgstaller, B., Konrad, F., Dietzel, M., Immenhauser, A., Mavromatis, V., 2017a. Control of $\mathrm{Mg}^{2+} / \mathrm{Ca}^{2+}$ activity ratio on the formation of crystalline carbonate minerals via an amorphous precursor. Crystal Growth \& Design 17, 1069-1078.

Purgstaller, B., Dietzel, M., Baldermann, A., Mavromatis, V., 2017b. Control of temperature and aqueous $\mathrm{Mg}^{2+} / \mathrm{Ca}^{2+}$ ratio on the (trans-) formation of ikaite. Geochimica et Cosmochimica Acta 217, 128-143.

Putnis, A., 2009. Mineral Replacement Reactions, Reviews in Mineralogy and Geochemistry 70, 87-124.

Putnis, A., Austrheim, H., 2013. Mechanisms of metasomatism and metamorphism on the local mineral scale: The role of dissolution-reprecipitation during mineral re-equilibration. In: Harlov, D.E, Austrheim, H. (Eds.), Metasomatism and the Chemical Transformation of Rock, Springer, Berlin, pp. 141-170.

Railsback, L.B., Dabous, A.A., Osmond, J.K., Fleisher, C.J., 2002. Petrographic and geochemical screening of speleothems for U-series dating: an example from recrystallized speleothems from Wadi Sannur Cavern, Egypt. Journal of Cave and Karst Studies 64, 108-116.

Ramseyer, K., Miano, T.M., D'orazio, V., Wildberger, A., Wagner, T., Geister, J., 1997. Nature and origin of organic matter in carbonates from speleothems, marine cements and coral skeletons. Organic Geochemistry 26, 361-378. 
Rao, C.R., Mehrotra, P.N., 1978. Differential thermal analysis and infrared studies on the effect of impurities on aragonite-calcite transformation. Canadian Journal of Chemistry 56, 32-35.

Riechelmann, S., Mavromatis, V., Buhl, D., Dietzel, M., Eisenhauer, A., Immenhauser, A., 2016. Impact of diagenetic alteration on brachiopod shell magnesium isotope $\left(\delta^{26} \mathrm{Mg}\right)$ signatures: Experimental versus field data. Chemical Geology, 440, 191-206.

Ritter, A.-C., Mavromatis, V., Dietzel, M., Kwiecien, O., Wiethoff, F., Griesshaber, E., Casella, L.A., Schmahl, W.W., Koelen, J., Neuser, R.D., Leis, A., Buhl, D., Niedermayr, A., Breitenbach, S.F.M., Bernasconi, S.M., Immenhauser, A,. 2017. Exploring the impact of diagenesis on (isotope) geochemical and microstructural alteration features in biogenic aragonite. Sedimentology 64, 1354-1380.

Rollion-Bard, C., Mangin, D., Champenois, M., 2007. Development and application of oxygen and carbon isotopic measurements of biogenic carbonates by ion microprobe. Geostandards and Geoanalytical Research 31, 39-50.

Rollion-Bard, C., Blamart, D., 2015. Possible controls on Li, Na, and Mg incorporation into aragonite coral skeletons. Chemical Geology 396, 98-111.

Sandberg, P.A., 1983. An oscillating trend in Phanerozoic non-skeletal carbonate mineralogy. Nature 305, 19-22. 
Sandstrom, M.W., Tirendi, F., Nott, A., 1986. Direct determination of organic carbon in modern reef sediments and calcareous organisms after dissolution of carbonate. Marine Geology 70, 321329.

Schöne, B.R., Zhang, Z., Jacob, D., Gillikin, D.P., Tütken, T., Garbe-Schönberg, D., McConnaughey, T., Soldati, A., 2010. Effect of organic matrices on the determination of the trace element chemistry $(\mathrm{Mg}, \mathrm{Sr}, \mathrm{Mg} / \mathrm{Ca}, \mathrm{Sr} / \mathrm{Ca})$ of aragonitic bivalve shells (Arctica islandica) — Comparison of ICP-OES and LA-ICP-MS data. Geochemical Journal 44, 23-37.

Schöne, B.R., 2013. Arctica islandica (Bivalvia): a unique paleoenvironmental archive of the northern North Atlantic Ocean. Global and Planetary Change 111, 199-225.

Schroeder, J.H., 1969. Experimental dissolution of calcium, magnesium, and strontium from recent biogenic carbonates: a model of diagenesis. Journal of Sedimentary Research 39.

Smith, S.V., Buddemeier, R.W., Redalje, R.C., Houck, J.E., 1979. Strontium-calcium thermometry in coral skeletons. Science 204, 404-407.

Staudigel, P.T., Swart, P.K., 2016. Isotopic behavior during the aragonite-calcite transition: Implications for sample preparation and proxy interpretation. Chemical Geology 442, 130-138. 
Sverjensky, D.A., 1984. Prediction of Gibbs free energies of calcite-type carbonates and the equilibrium distribution of trace elements between carbonates and aqueous solutions. Geochimica et Cosmochimica Acta 48, 1127-1134.

Swart, P.K., 1981. The strontium, magnesium and sodium composition of recent scleractinian coral skeletons as standards for palaeoenvironmental analysis. Palaeogeography, Palaeoclimatology, Palaeoecology 34, 115-136.

Swart, P. K., 2015. The geochemistry of carbonate diagenesis: The past, present and future. Sedimentology 62, 1233-1304.

Tardy, Y., Gartner, L., 1977. Relationships among Gibbs energies of formation of sulfates, nitrates, carbonates, oxides and aqueous ions. Contributions to Mineralogy and Petrology 63, 89102.

Terakado, Y., Ofuka, Y., Tada, N., 2010. Rare earth elements, Sr, Ba, Fe, and major cation concentrations in some living foraminiferal tests collected from Iriomote Island, Japan: An exploration for trace element behavior during biogenic calcium carbonate formation. Geochemical Journal 44, 315-322.

Toland, H., Perkins, B., Pearce, N., Keenan, F., Leng, M.J., 2000. A study of sclerochronology by laser ablation ICP-MS presented at the 2000 Winter Conference on Plasma Spectrochemistry, Fort Lauderdale, FL, USA, January 10-15, 2000. Electronic Supplementary Information 
available. See http://www. rsc. org/suppdata/ja/b0/b002014l. Journal of Analytical Atomic Spectrometry 15, 1143-1148.

van der Kooij, B., Immenhauser, A., Csoma, A., Bahamonde, J., Steuber, T., 2009. Spatial geochemistry of a Carboniferous platform-margin-to-basin transect: Balancing environmental and diagenetic factors. Sedimentary Geology 219, 136-150.

Veizer, J., Ala, D., Azmy, K., Bruckschen, P., Buhl, D., Bruhn, F., Carden, G.A., Diener, A., Ebneth, S., Godderis, Y., Jasper, T., 1999. $87 \mathrm{Sr} / 86 \mathrm{Sr}, \delta 13 \mathrm{C}$ and $\delta 18 \mathrm{O}$ evolution of Phanerozoic seawater. Chemical Geology 161, 59-88.

vS Hood, A., Planavsky, N.J., Wallace, M.W. and Wang, X., 2018. The effects of diagenesis on geochemical paleoredox proxies in sedimentary carbonates. Geochimica et Cosmochimica Acta, 232, pp.265-287.

Walter, L.M., 1985. Relative reactivity of skeletal carbonates during dissolution: implications for diagenesis. In: Schneidermann, N., Harris, P.M. (Eds.), Carbonate Cements. The Society of Economic Paleontologists and Mineralogists, Oklahoma, USA, https://doi.org/10.2110/pec.85.36.

Walter, L.M., 1986. Relative efficiency of carbonate dissolution and precipitation during diagenesis: a progress report on the role of solution chemistry, In: Gautier, D.L. (Ed.), Roles of 
Organic Matter in Sediment Diagenesis, The Society of Economic Paleontologists and Mineralogists, Oklahoma, USA, https://doi.org/10.2110/pec.86.38.0001.

Wassenburg, J.A., Scholz, D., Jochum, K.P., Cheng, H., Oster, J., Immenhauser, A., Richter, D.K., Haeger, T., Jamieson, R.A., Baldini, J.U.L., Hoffmann, D., 2016. Determination of aragonite trace element distribution coefficients from speleothem calcite-aragonite transitions. Geochimica et Cosmochimica Acta 190, 347-367.

Weber, J.N., 1973. Incorporation of strontium into reef coral skeletal carbonate. Geochimica et Cosmochimica Acta 37, 2173-2190.

Winland, H.D., 1969. Stability of calcium carbonate polymorphs in warm, shallow seawater. Journal of Sedimentary Research 39, 1579-1587.

Zheng, Y.F., 1999. Oxygen isotope fractionation in carbonate and sulfate minerals. Geochemical Journal 33, 109-126. 


\section{Figure and table captions}

Figure 1. Overview images of samples used for the hydrothermal experiments. Images were taken prior to subsampling and alteration.

Figure 2. Textural comparison of all sample types, including the unaltered and altered specimen. All overview scale bars are $1 \mathrm{~mm}$. The width of the images are as follows: $5 \mathrm{x}=4 \mathrm{~mm}, 20 \mathrm{x}=1.5$ $\mathrm{mm} . \mathrm{LPL}=$ linearly (normal) polarized light, $\mathrm{XPL}=$ cross polarized light, $\mathrm{FL}=$ fluorescence light.

Figure 3. EBSD maps and locations. For mineral phases, blue $=$ aragonite, red $=$ calcite, and green $=$ dolomite For crystal orientation maps, different colors represent different crystal axis orientations. The higher number of colors indicates higher disorder, and increased recrystallization.

Figure 4. Electron microprobe maps of the altered areas of the four sample types. Differences are relative, with the units in counts (cts). Brighter, warmer colors indicate higher relative concentrations, while cooler colors indicate lower relative concentrations.

Figure 5. Porosimetry data from Mercury Injection Capillary Pressure (MICP) analysis. Note that permeability is on a log scale. All samples measured were unaltered specimens of similar size as the experimentally altered subsamples. 
Figure 6. Elemental composition (ICP analysis) of experimental fluids following the experiments. Concentrations have been normalized to the initial fluid. Values above 0 indicate the element was released into the fluid from the solid phase. Values below 0 (indicated by the black line) suggest uptake of the element from the fluid into the solid.

Figure 7. Isotopic compilation of unaltered and altered specimen. A) Box and whisker plot showing distribution of data. Speleothem samples are shown in orange, bivalve samples in gray, and coral samples in blue. Sample point locations and further information can be found in the supplemental material. B) Cross plot of all data shown in figure A. Same color indications apply.

Table 1. Comparison of textural, porosimetry, crystallographic, elemental, and isotopic features. Blank boxes indicate no data was collected. 
Table 1

\begin{tabular}{|c|c|c|c|c|c|c|c|c|c|c|c|c|}
\hline $\begin{array}{c}\text { Samp } \\
\text { le } \\
\text { type }\end{array}$ & $\begin{array}{c}\text { Tem } \\
\text { p. } \\
\left({ }^{\circ} \mathrm{C}\right)\end{array}$ & $\begin{array}{c}\text { Dur } \\
\text { atio } \\
n \\
\text { (da } \\
\text { ys) }\end{array}$ & $\begin{array}{c}\text { Textur } \\
\text { es }\end{array}$ & $\begin{array}{c}\text { Por } \\
\text { osit } \\
y \\
(\%) \\
\pm s\end{array}$ & $\begin{array}{c}\text { Perm } \\
\text { eabili } \\
\text { ty } \\
\text { (mD) } \\
\pm s\end{array}$ & $\begin{array}{l}\text { Fluore } \\
\text { scence }\end{array}$ & $\begin{array}{c}\text { Mine } \\
\text { ralog } \\
y \\
\text { XRD } \\
(\%)\end{array}$ & $\begin{array}{c}\text { Eleme } \\
\text { ntal } \\
\text { distri } \\
\text { butio } \\
\text { n } \\
\text { ICP }\end{array}$ & $\begin{array}{c}\text { Crystall } \\
\text { ograph } \\
y \\
\text { EBSD }\end{array}$ & $\begin{array}{c}\text { Dri } \\
\text { Ile } \\
\text { d } \\
\delta^{18} \\
0 \\
\text { (av } \\
\text { g.) } \\
\pm s\end{array}$ & $\begin{array}{c}\text { Dri } \\
\text { Ile } \\
\text { d } \\
\delta^{13} \\
\text { C } \\
\text { (av } \\
\text { g.) } \\
\pm s\end{array}$ & $\begin{array}{c}\text { SI } \\
\text { M } \\
\text { S } \\
\delta^{1} \\
{ }^{8} O^{1} \\
\text { (a } \\
\text { vg } \\
.) \\
\pm \\
\text { S }\end{array}$ \\
\hline & $\begin{array}{c}\text { Unal } \\
\text { tere } \\
\mathrm{d} \\
\end{array}$ & 0 & $\begin{array}{c}\text { Single } \\
\text { crystal, } \\
\text { with } \\
\text { smoot } \\
\mathrm{h} \\
\text { edges, } \\
\text { consisti } \\
\text { ng of } \\
\text { anhedr } \\
\text { al } \\
\text { subcrys } \\
\text { tals }\end{array}$ & & & $\begin{array}{c}\text { No } \\
\text { fluores } \\
\text { cence }\end{array}$ & $\begin{array}{c}A r=1 \\
00\end{array}$ & & & & & \\
\hline $\begin{array}{c}\text { Single } \\
\text { crysta } \\
\text { I }\end{array}$ & 200 & 10 & $\begin{array}{c}\text { Single } \\
\text { crystal, } \\
\text { with a } \\
\text { neomo } \\
\text { rphose } \\
\text { d outer } \\
\text { rim, } \\
\text { and } \\
\text { microfr } \\
\text { actures } \\
\text { within } \\
\text { the } \\
\text { crystal } \\
\text { center }\end{array}$ & & & $\begin{array}{l}\text { Only } \\
\text { slight } \\
\text { fluores } \\
\text { cence } \\
\text { in the } \\
\text { altered } \\
\text { rim }\end{array}$ & $\begin{array}{c}\mathrm{Ar}=9 \\
9 \\
\mathrm{Dol}= \\
1\end{array}$ & $\begin{array}{l}\uparrow \mathrm{Mg} \\
\text { and } \\
\mathrm{Ca}, \\
\text { and } \\
\downarrow \mathrm{Sr} \\
\text { along } \\
\text { the } \\
\text { recrys } \\
\text { tallize } \\
\mathrm{d} \\
\text { sampl } \\
\text { e rim. } \\
\text { Sr } \\
\text { zonati } \\
\text { on } \\
\text { within } \\
\text { the } \\
\text { crysta } \\
\text { I } \\
\text { cente }\end{array}$ & $\begin{array}{c}\text { Domin } \\
\text { ant } \\
\text { preserv } \\
\text { ation } \\
\text { of } \\
\text { single } \\
\text { crystal, } \\
\text { formati } \\
\text { on of } \\
\text { new } \\
\text { crystals } \\
\text { with } \\
\text { rando } \\
\text { m size } \\
\text { and } \\
\text { orienta } \\
\text { tion }\end{array}$ & & & \\
\hline
\end{tabular}




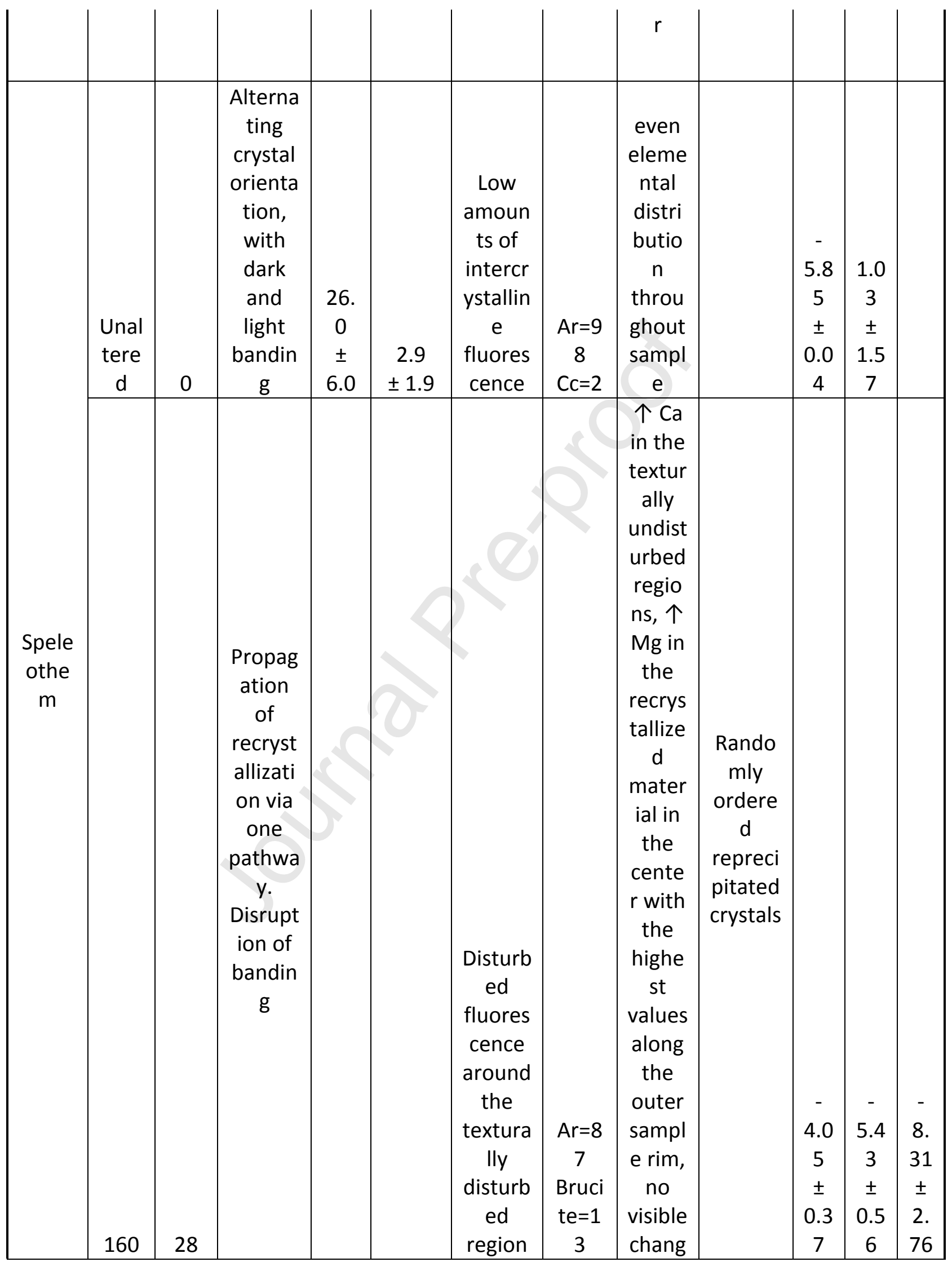




\begin{tabular}{|c|c|c|c|c|c|c|c|c|c|c|c|c|}
\hline & & & & & & & & $\begin{array}{c}\text { es to } \\
\mathrm{Sr}\end{array}$ & & & & \\
\hline & $\begin{array}{c}\text { Unal } \\
\text { tere } \\
\mathrm{d}\end{array}$ & 0 & $\begin{array}{l}\text { Growth } \\
\text { band } \\
\text { laminat } \\
\text { ions, } \\
\text { and } \\
\text { outer } \\
\text { periost } \\
\text { racum }\end{array}$ & $\begin{array}{c}3.5 \\
\pm \\
1.1\end{array}$ & $\begin{array}{r}17.8 \\
\pm 8.6\end{array}$ & $\begin{array}{c}\text { Highes } \\
\text { t in } \\
\text { lamina } \\
\text { tions }\end{array}$ & $\begin{array}{c}A r=1 \\
00\end{array}$ & $\begin{array}{c}\text { 个 Sr } \\
\& \mathrm{~S} \text { in } \\
\text { growt } \\
\mathrm{h} \\
\text { bands } \\
\text {, also } \\
\text { slightl } \\
y \\
\text { enrich } \\
\text { ed in } \\
\mathrm{Mg}\end{array}$ & & $\begin{array}{c}3.0 \\
23 \\
\pm \\
0.2 \\
0\end{array}$ & $\begin{array}{c}2.3 \\
5 \\
\pm \\
0.3 \\
2 \\
\end{array}$ & \\
\hline $\begin{array}{c}\text { Bivalv } \\
\mathrm{e}\end{array}$ & 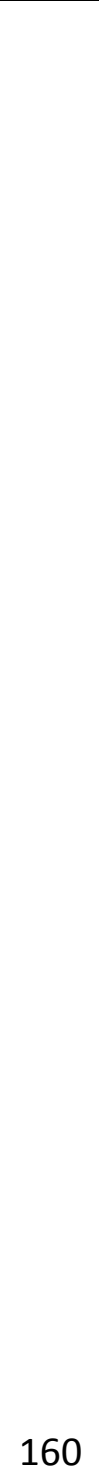 & 28 & $\begin{array}{c} \\
\\
\text { Distinct } \\
\text { reactio } \\
\text { n front. } \\
\text { Partiall } \\
\text { y well } \\
\text { preserv } \\
\text { ed } \\
\text { laminat } \\
\text { ions, } \\
\text { and } \\
\text { partiall } \\
\text { y } \\
\text { blocky/ } \\
\text { angular } \\
\text { crystals }\end{array}$ & & & $\begin{array}{c}\text { Reduc } \\
\text { ed in } \\
\text { neomo } \\
\text { rphose } \\
d \text { areas }\end{array}$ & $\begin{array}{c}\mathrm{Ar}=7 \\
7 \\
\mathrm{Cc}=2 \\
3\end{array}$ & $\begin{array}{c}\text { } \mathrm{Mg} \\
\text { aroun } \\
\mathrm{d} \\
\text { sampl } \\
\text { e rim } \\
\text { and } \\
\text { micro } \\
\text { fractu } \\
\text { res, } \mathrm{S} \\
\text { displa } \\
\text { ced in } \\
\text { recrys } \\
\text { tallize } \\
\mathrm{d} \\
\text { regio } \\
\text { ns, Sr } \\
\text { seemi } \\
\text { ngly } \\
\text { undist } \\
\text { urbed } \\
\text {, but } \\
\text { slightl } \\
\text { y } \\
\text { lower } \\
\text { in } \\
\text { recrys } \\
\text { tallize } \\
\mathrm{d} \\
\text { mater }\end{array}$ & $\begin{array}{l}\text { Multi- } \\
\text { phase } \\
\text { stabiliz } \\
\text { ation } \\
\text { to } \\
\text { larger, } \\
\text { blocky } \\
\text { crystals }\end{array}$ & $\begin{array}{c}- \\
12 . \\
19 \\
\pm \\
11 . \\
50\end{array}$ & $\begin{array}{c}2.2 \\
1 \\
\pm \\
0.3 \\
3\end{array}$ & $\begin{array}{c} \\
- \\
26 \\
.1 \\
6 \\
\pm \\
17 \\
.3 \\
0\end{array}$ \\
\hline
\end{tabular}




\begin{tabular}{|c|c|c|c|c|c|c|c|c|c|c|c|c|}
\hline \multirow[t]{2}{*}{ Coral } & $\begin{array}{c}\text { Unal } \\
\text { tere } \\
\mathrm{d}\end{array}$ & 0 & $\begin{array}{c}\text { Fine Ar } \\
\text { needle } \\
s(<5 \\
\mu \mathrm{m}), \\
\text { and } \\
\text { unifor } \\
\mathrm{m} \\
\text { distrib } \\
\text { ution } \\
\text { of pore } \\
\text { space }\end{array}$ & $\begin{array}{c}41 . \\
6 \\
\pm \\
1.2\end{array}$ & $\begin{array}{c}2607 \\
2 \\
\pm \\
623.2\end{array}$ & $\begin{array}{c}\text { Homog } \\
\text { enous } \\
\text { and at } \\
\text { rims }\end{array}$ & $\begin{array}{c}A r=1 \\
00\end{array}$ & $\begin{array}{c}\uparrow \mathrm{Mg} \\
\text { towar } \\
\text { ds } \\
\text { cente } \\
r, \mathrm{Sr} \\
\text { homo } \\
\text { genou } \\
\mathrm{s} \text { and } \\
\text { deple } \\
\text { ted at } \\
\text { conne } \\
\text { ction } \\
\text { bridg } \\
\text { es, } \\
\text { slight } \\
\uparrow \mathrm{S} \\
\text { towar } \\
\text { ds } \\
\text { cente } \\
r\end{array}$ & & $\begin{array}{c}- \\
4.1 \\
5 \\
\pm \\
0.1 \\
9\end{array}$ & $\begin{array}{c}- \\
1.8 \\
6 \\
\pm \\
0.2 \\
6\end{array}$ & \\
\hline & 160 & 28 & $\begin{array}{c}\text { Precipi } \\
\text { tation } \\
\text { of } \\
\text { pore- } \\
\text { filling } \\
\text { Ar } \\
\text { needle } \\
\text { s. } \\
\text { Darken } \\
\text { ing and } \\
\text { increas } \\
\text { ed } \\
\text { infilling } \\
\text { along } \\
\text { the } \\
\text { sample } \\
\text { edge }\end{array}$ & & & $\begin{array}{c}\text { Enrich } \\
\text { ed } \\
\text { toward } \\
\text { s the } \\
\text { center, } \\
\text { lower } \\
\text { margin } \\
\text {, and } \\
\text { patchy } \\
\text { accum } \\
\text { ulation } \\
\text { s }\end{array}$ & $\begin{array}{c}\mathrm{Ar}=1 \\
00\end{array}$ & $\begin{array}{c}\uparrow \mathrm{Mg} \\
\text { in } \\
\text { ceme } \\
\mathrm{nts}, \mathrm{Sr} \\
\uparrow \text { in } \\
\text { ceme } \\
\text { nts, S } \\
\downarrow \text { in } \\
\text { ceme } \\
\text { nts }\end{array}$ & $\begin{array}{c}\text { Compa } \\
\text { ratively } \\
\text { large } \\
\text { crystals } \\
\text { oriente } \\
\text { d near- } \\
\text { perpen } \\
\text { dicular } \\
\text { to } \\
\text { initial } \\
\text { pore } \\
\text { space }\end{array}$ & $\begin{array}{c}- \\
6.5 \\
6 \\
\pm \\
0.6 \\
5\end{array}$ & $\begin{array}{c}- \\
0.7 \\
6 \\
\pm \\
0.8 \\
4\end{array}$ & $\begin{array}{c}- \\
13 \\
.3 \\
\pm \\
3 . \\
28\end{array}$ \\
\hline
\end{tabular}




\section{Declaration of interests}

$\bigotimes$ The authors declare that they have no known competing financial interests or personal relationships that could have appeared to influence the work reported in this paper.

$\square$ The authors declare the following financial interests/personal relationships which may be considered as potential competing interests: 
Single Crystal

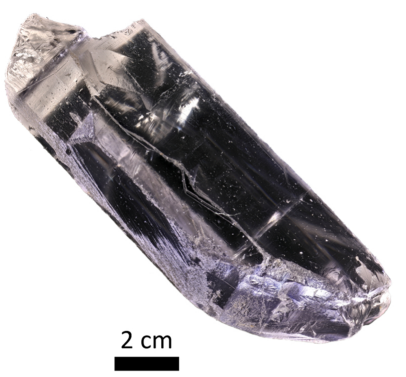

Speleothem

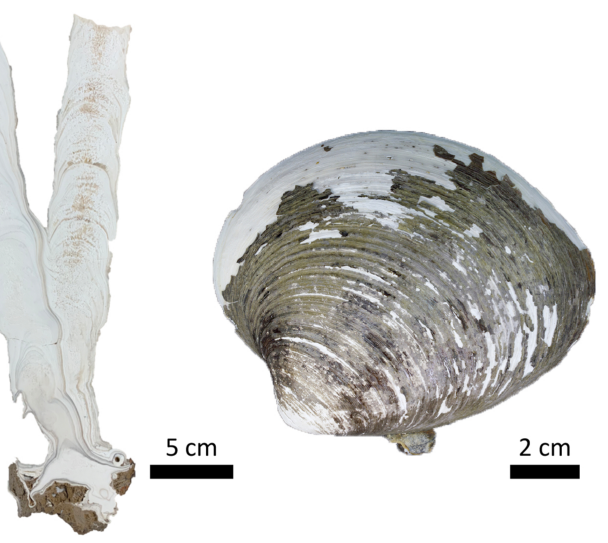

Coral

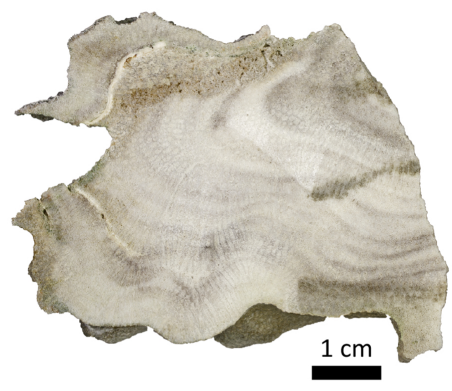

Figure 1 


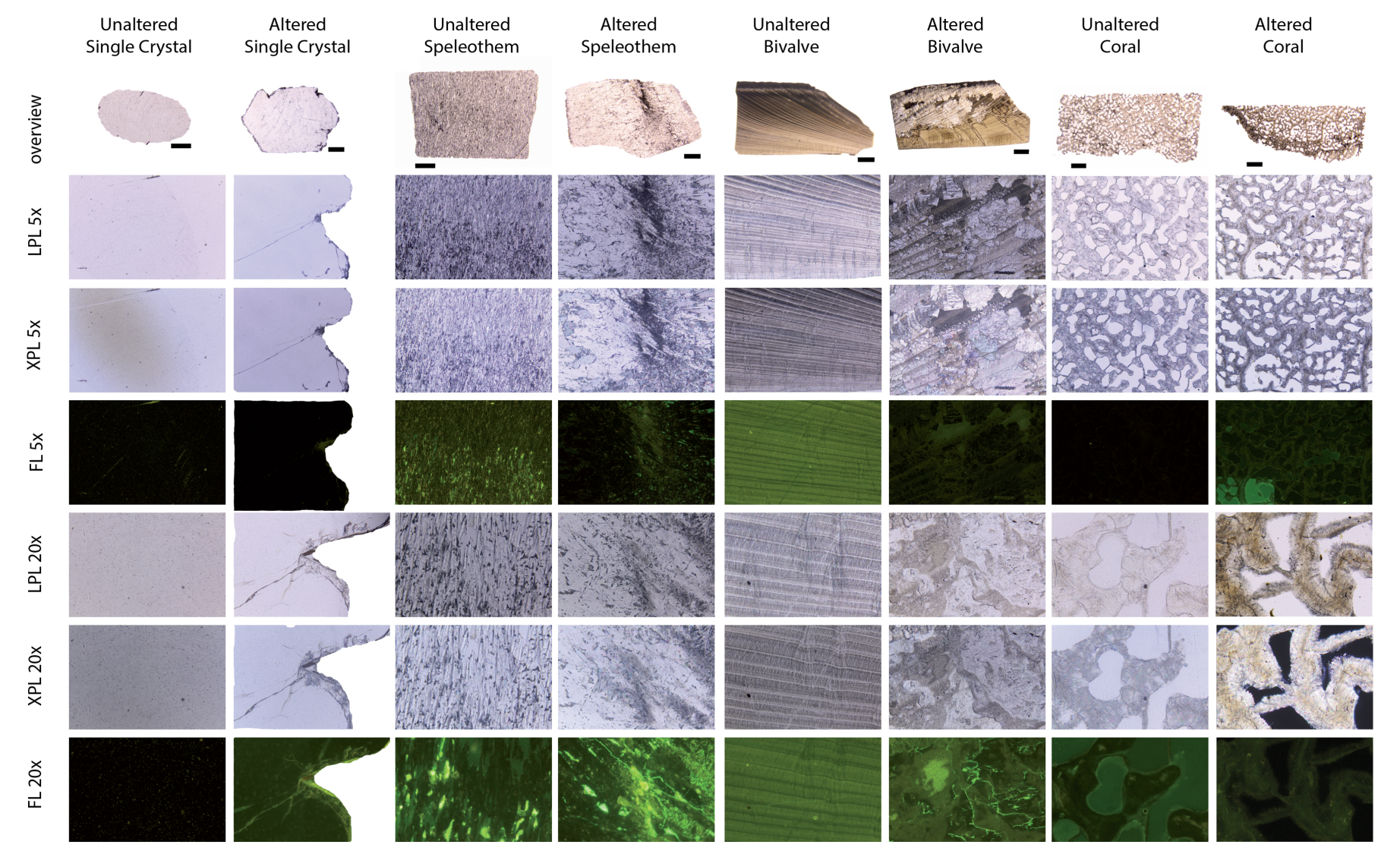

Figure 2 


\section{Single Crystal}

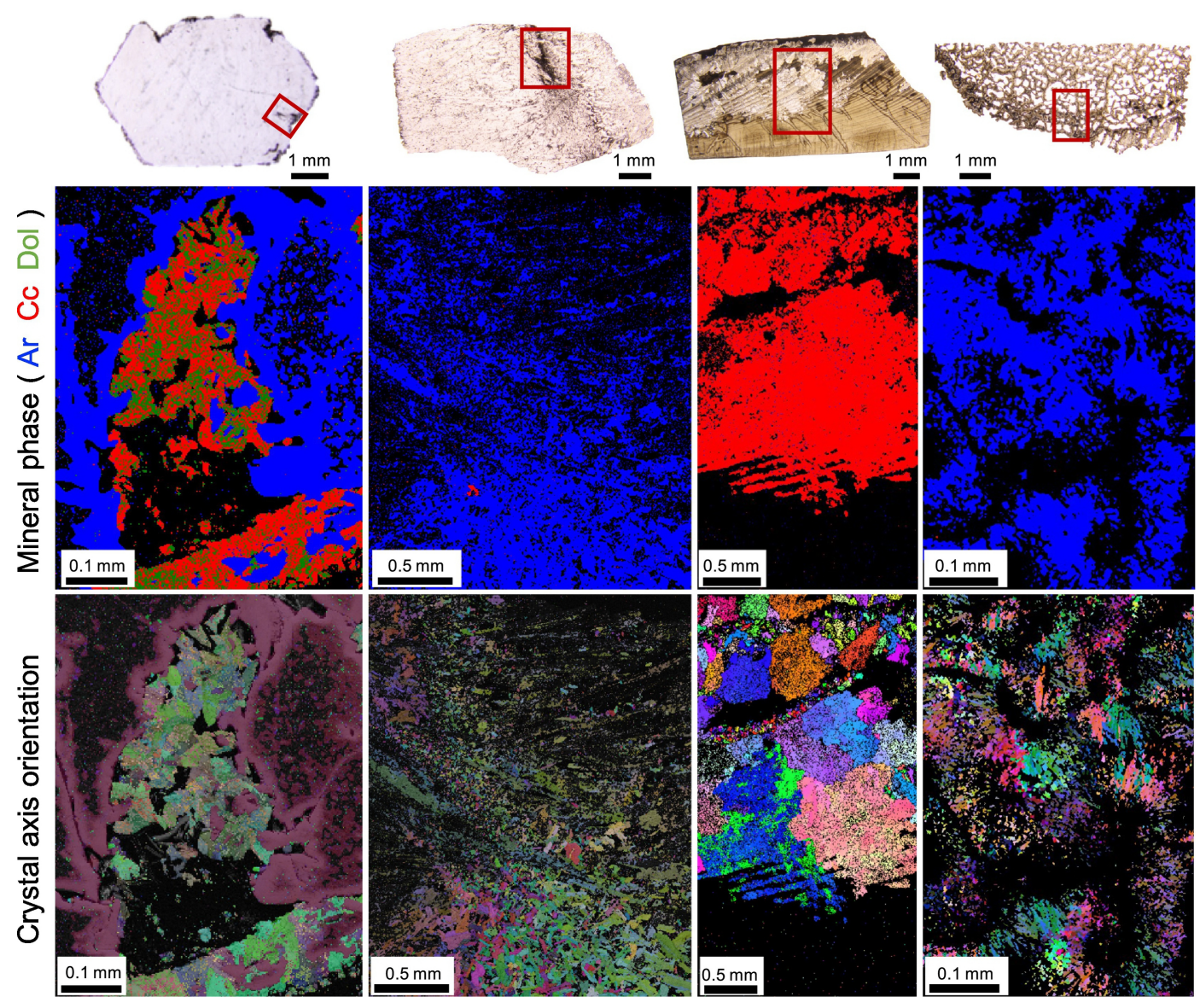

Figure 3 


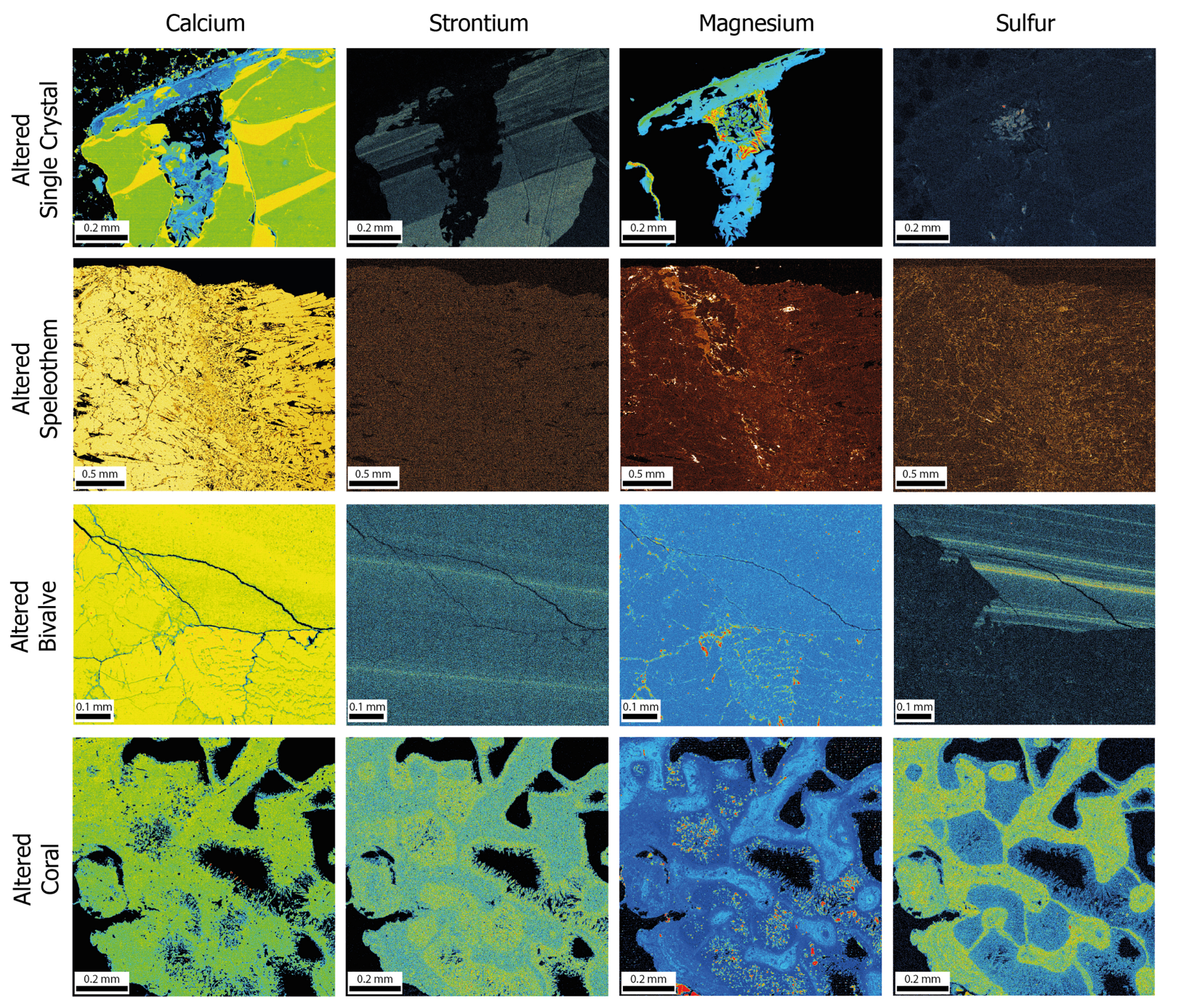

Figure 4 


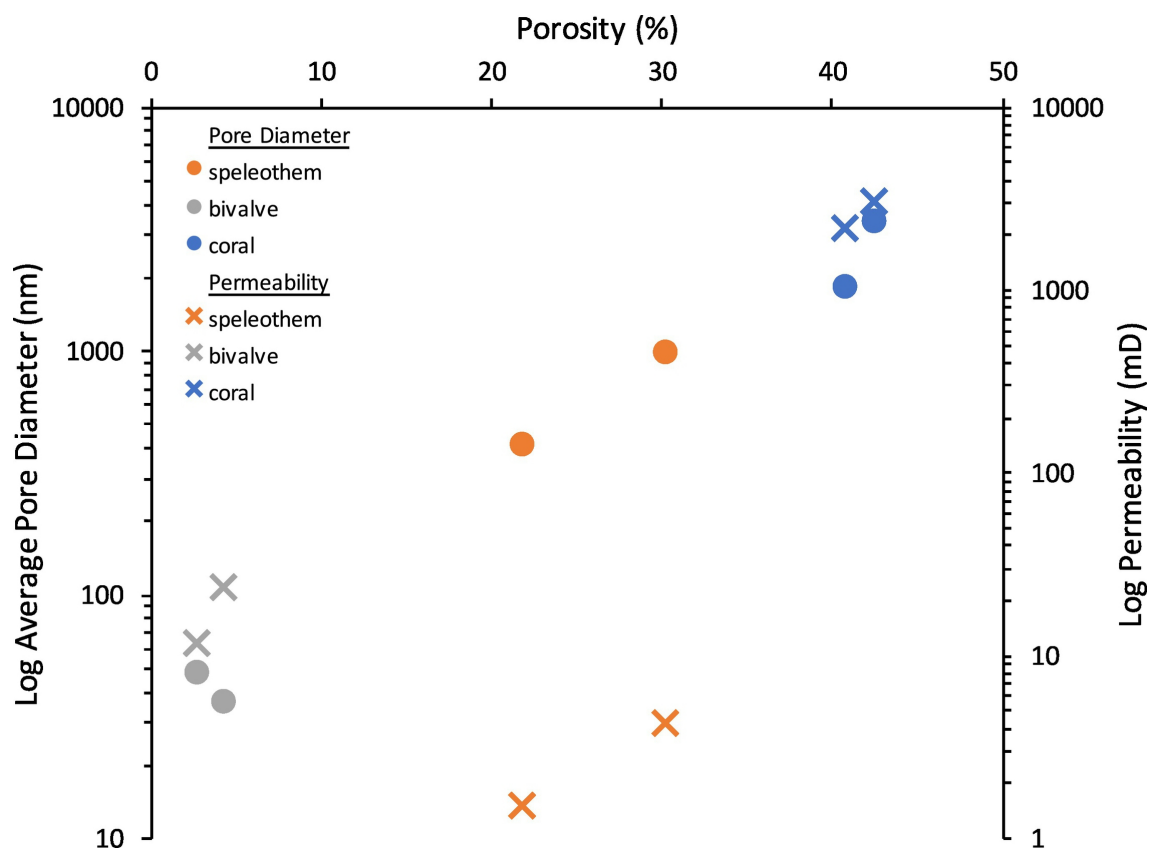

Figure 5 


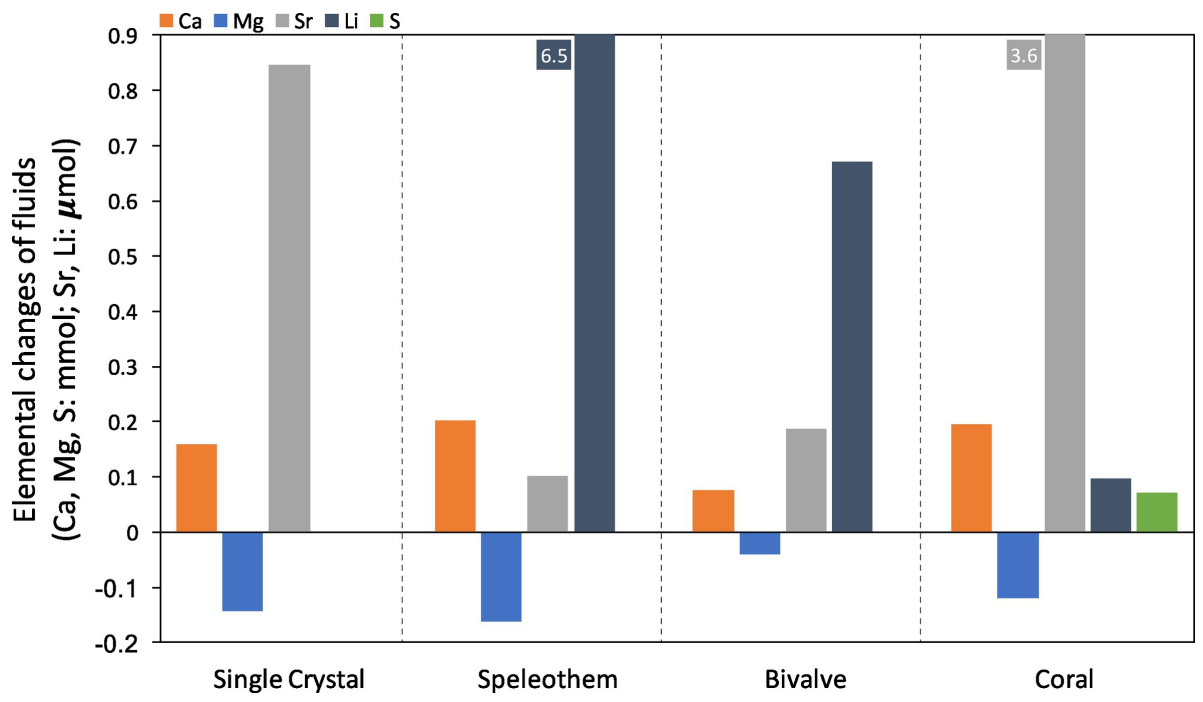

Figure 6 

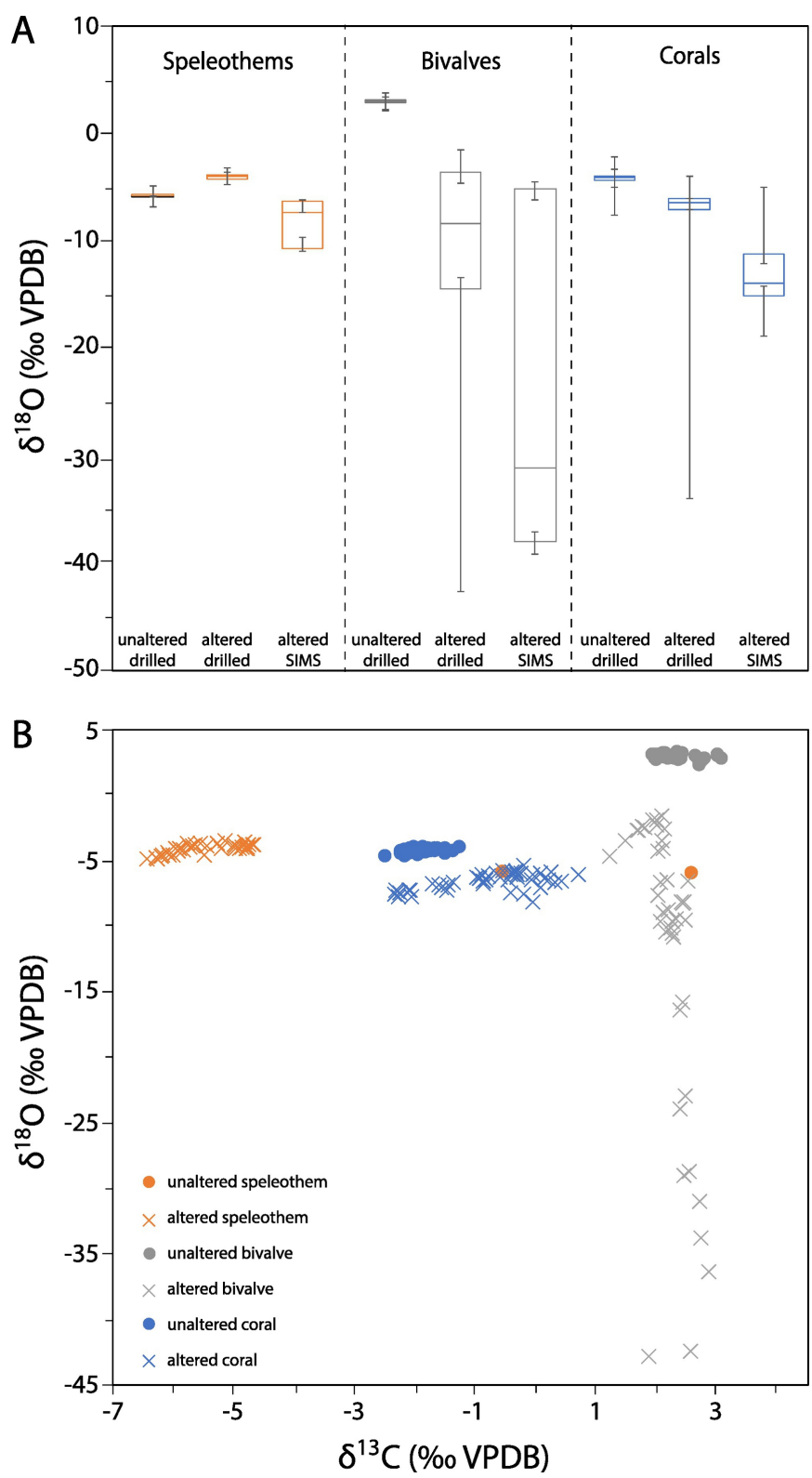